\title{
Substances of emerging concern in Baltic Sea water: Review on methodological advances for the environmental assessment and proposal for future monitoring
}

\author{
Marion Kanwischer (D), Noomi Asker, Ann-Sofie Wernersson, \\ Marisa A. Wirth, Kathrin Fisch, Elin Dahlgren, Helena Osterholz, \\ Friederike Habedank, Michael Naumann, Jaakko Mannio, \\ Detlef E. Schulz-Bull
}

Received: 11 March 2021/Revised: 27 August 2021 / Accepted: 6 September 2021 / Published online: 12 October 2021

\begin{abstract}
The Baltic Sea is among the most polluted seas worldwide. Anthropogenic contaminants are mainly introduced via riverine discharge and atmospheric deposition. Regional and international measures have successfully been employed to reduce concentrations of several legacy contaminants. However, current Baltic Sea monitoring programs do not address compounds of emerging concern. Hence, potentially harmful pharmaceuticals, UV filters, polar pesticides, estrogenic compounds, per- and polyfluoroalkyl substances, or naturally produced algal toxins are not taken into account during the assessment of the state of the Baltic Sea. Herein, we conducted literature searches based on systematic approaches and compiled reported data on these substances in Baltic Sea surface water and on methodological advances for sample processing and chemical as well as effect-based analysis of these analytically challenging marine pollutants. Finally, we provide recommendations for improvement of future contaminant and risk assessment in the Baltic Sea, which revolve around a combination of both chemical and effectbased analyses.
\end{abstract}

Keywords Baltic Sea - Bioassay · Biomarker . Effect-based methods - Instrumental analysis . Substances of emerging concern

Supplementary Information The online version of this article (https://doi.org/10.1007/s13280-021-01627-6) contains supplementary material, which is available to authorized users.

\section{CONTAMINANT ASSESSMENT IN THE BALTIC SEA}

Since the onset of industrialization at the end of the nineteenth century, large amounts of industrially derived chemicals have been released into the environment. After discovering harmful effects on ecosystems, identification and regulation of certain persistent contaminants began in the 1970s, about three to four decades after their first use. For example, the environmental concentration of dichlorodiphenyltrichloroethylene (DDE), the degradation product of the organochlorine pesticide dichlorodiphenyltrichloroethane (DDT) was found to be strongly linked to egg shell thinning in birds. This had severe consequences for several species on the population level. However, retroactive studies showed that such effects already occurred in the early 1950s (Peakall 1993). Not only ecosystems but humans as well have been affected by persistent contaminants, even far away from the emission sources. For example, in the 1980s it was discovered that Arctic Inuit populations had high concentrations of polychlorinated biphenyls (PCBs) in breast milk (Dewailly et al. 1989). While national measures to regulate use and emissions of some of the organic pollutants were implemented in the 1970 s to 1980 s, the global convention on persistent organic pollutants, the Stockholm Convention, was ratified in 2004 (for an overview see HELCOM 2010). Nevertheless, a range of legacy contaminants are still present in the environment at high concentrations, emphasizing the importance of early detection of potential substances of concern.

Marine environments are receptors of environmental contaminants, stemming from land-based activities, entering the sea through riverine input or airborne deposition, as well as sea-based activities. Depending on their 
physicochemical characteristics, water contaminants either remain in the water column or bind to particles that are eventually deposited at the seafloor. However, sediment contaminants can be re-mobilized and re-enter the water column, e.g., due to physical disturbance. Aquatic organisms are exposed to these contaminants from both water and sediment, but also indirectly, through the food chain.

The Baltic Sea is one of the most polluted seas in the world. It is a semi-enclosed sea with substantial riverine inflow with an annual average of about $14000 \mathrm{~m}^{3} / \mathrm{a}$ (Johansson 2018). Its catchment area is about four times the size of the Baltic Sea itself, corresponding to about half of the size of Europe. Rivers carry large amounts of nutrients and hazardous contaminants into the Baltic Sea (Fig. 1). Besides this, there is also substantial airborne contaminant deposition of heavy metals and organic hazardous substances on the water surface (HELCOM 2018b).

Although the concentrations of several legacy pollutants are still exceeding different types of environmental quality standards, the measures have indeed led to decreasing concentration trends in the Baltic Sea in most cases (HELCOM 2018c,d), which is most evident in marine biota (Gustavsson 2010).

A revision proposal of the current monitoring system for the Baltic Sea including monitoring strategies for hazardous substances was the overall objective of the EUfinanced BONUS SEAM project. It was concluded that current strategies in monitoring do not reflect compounds of emerging concern and it was recommended to increase efforts to determine relevant target substances and to appropriately address them in Baltic Sea monitoring (Kanwischer et al. 2019).

Analysis of seawater is most indicative of the contaminant sources and, thus, allows tracing their transport pathways into the Baltic Sea. However, there are only a few HELCOM water monitoring programs of hazardous substances in the Baltic Sea and the current programs generally address only a very limited number of the substances of emerging concern. Thus, seawater concentrations of, e.g., pharmaceuticals and UV filters are currently

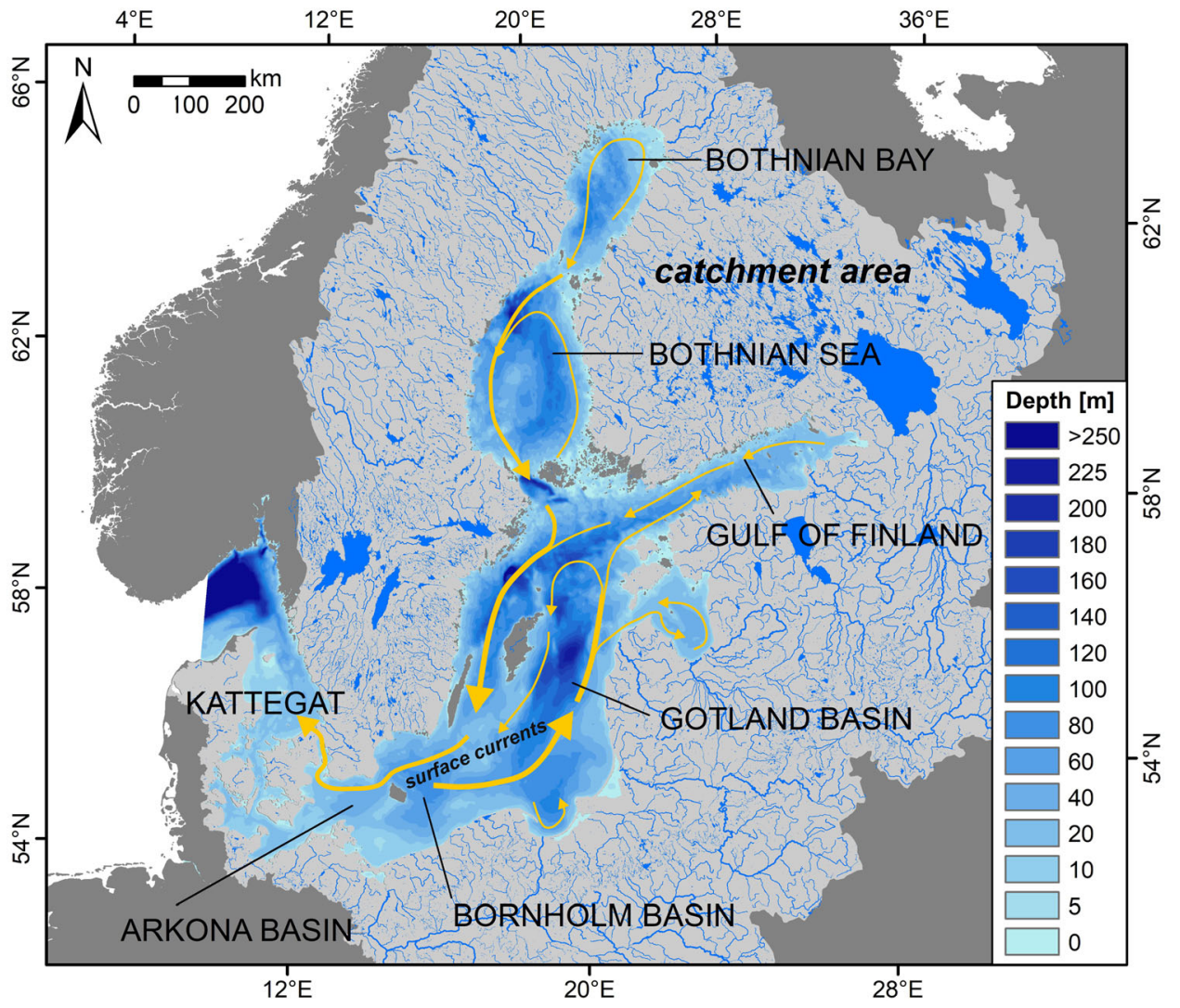

Fig. 1 Map of the Baltic Sea and its catchment area. The Baltic Sea has a surface area of $412560 \mathrm{~km}^{2}$, a water volume of $21631 \mathrm{~km}{ }^{3}$, and an average water depth of $52 \mathrm{~m}$ with a maximum of $460 \mathrm{~m}$ at the Landsort Deep. The sea floor topography structures the Baltic Sea into various subbasins divided by sill areas. It is characterized by a permanently stratified water column with brackish water of low salinity in the surface water fed by riverine runoff and a deep water layer of higher salinity influenced by rare salt-water inflow events from the North Sea/North Atlantic. There is a strong salinity gradient from the entrance in the western part of the Baltic Sea to the central and north-eastern part with salinities close to freshwater conditions in the Bothnian Bay (Feistel et al. 2008). Catchment area (1 $749209 \mathrm{~km}^{2}$ ) is shown in light gray; rivers (in total 8478) are shown as blue lines, their widths correspond to the river length. The arrows show the main Baltic Sea surface water currents 
not easy to take into account in the assessment of the state of the Baltic Sea. Moreover, analyzing the very low concentrations typical for marine waters remains a constant challenge. Beside anthropogenically induced contamination, harmful cyanobacterial blooms in the Baltic Sea have increased in frequency, biomass, and duration in the last decades (e.g., Finni et al. 2001), but algal toxin concentrations are not regularly monitored. Finally, effects of emerging concern such as endocrine disruption are not addressed, as well.

Therefore, this study aims (i) to review reported Baltic Sea data for surface water concentrations on selected contaminants of emerging concern and in vitro bioassays measuring estrogenic effects as well as naturally produced algal toxins; (ii) to describe state-of-the-art methodological advances for the chemical analysis of these compounds in seawater and the use of effect-based methods; (iii) to provide recommendations for improved monitoring strategies to assess the state of the Baltic Sea also covering the selected contaminants of emerging concern.

\section{APPROACH}

In this review, we focus on selected compound groups that are of emerging concern: pharmaceuticals, polar pesticides, estrogenic substances, per- and polyfluoroalkyl substances (PFAS), UV filters, and algal toxins (e.g., Diamond et al. 2011) (Table 1).

A literature search was conducted to collect data on these substance groups in Baltic Sea surface water. The literature was also reviewed for state-of-the-art methods and recently reported advances in the field of sample processing, analysis approaches, and effect-based methods relevant for the determination, identification, and assessment of the substances addressed herein with particular focus on marine water. The searches were conducted, basically, following the process described by Mengist et al. (2020) and the details of the searches are summarized in Table S1.

\section{ANTHROPOGENIC AND NATURALLY DERIVED SUBSTANCES OF EMERGING CONCERN IN THE BALTIC SEA}

\section{Current inclusion in water policy}

Monitoring of organic hazardous substances in the Baltic Sea is predominantly conducted under the policies of the HELCOM commitment within the scope of the Baltic Sea Action Plan and EU legislation. Within the Water Framework Directive (WFD) context, priority substances listed in the Environmental Quality Standards Directive (EQSD) need to be monitored in water bodies they are emitted into. Monitoring data are used in the chemical status assessment. Substances included in the Watch list, established according to the EQSD, are also to be monitored, but during a shorter time period and on a limited number of sites. When sufficient monitoring data are available to draw conclusions about whether or not the substance could be of EUwide concern and therefore should be considered for inclusion in the EQSD, the substance is removed from this list. In addition, each member state has an individual list of WFD river basin specific pollutants (RBSP) and the results are taken into account in the ecological status classification. Within the Marine Strategy Framework Directive (MSFD), both priority substances and RBSPs of relevance to the marine environment are taken into account in the assessment of the environmental status. Individual member states have also implemented additional MSFD indicators such as effect-based methods. Assessment under HELCOM relies on the indicator concept. Core indicators are agreed along with quantitative threshold values, whereas pre-core indicators have not reached the core indicator status yet and data do not enter the holistic assessment. The assessment is mostly based on chemical analytical data. So far, only the mandatory effect-based method imposex is included in the HELCOM monitoring program, which is very specific to tributyltin and cannot be expected to respond to any of the substances of emerging concern in focus of this review. Table 2 provides an overview of how the substances in focus of this review are currently addressed in HELCOM and the MSFD/WFD context.

\section{Reported data for Baltic Sea surface water}

The herein addressed compounds are generally analyzed in a campaign-wise manner, such as screening studies, or within research contexts. In the following, they are shortly introduced and accessible data published for Baltic Sea surface water are summarized in Table 3.

The presence of pharmaceuticals and their transformation products in the marine environment has received large attention in recent years due to observed harmful effects on non-target species after environmental exposure (e.g., Alygizakis et al. 2016; reviewed by Białk-Bielińska et al. 2016; Ojemaye and Petrik 2019). They enter the marine environment indirectly with treated and untreated waste water from households, agriculture, or industry (Heberer and Ternes 2006; Gaw et al. 2014). Their ecotoxicity presumably derives from their mode of action. Gunnarsson et al. (2008) showed that there are drug targets conserved among humans and aquatic species, which is a basis for potential interaction of pharmaceuticals with wildlife when released into the environment. 
Table 1 Compound groups and chemical structures of example substances addressed in this review. Data for the octanol-water-partition coefficient $\left(\log K_{\mathrm{OW}}\right)$ and water solubility were obtained from the databases: ${ }^{a}$ Pubchem (https://pubchem.ncbi.nlm.nih.gov/ accessed 2021/01/ 21), ${ }^{b}$ European Chemicals Agency (https://echa.europa.eu/de/ accessed 2021/01/21), ${ }^{\mathrm{c}}$ Toxin and Toxin Target Database (http://www.t3db.ca/ toxins accessed 2021/01/25), ${ }^{\mathrm{d} D r u g B a n k}$ (https://go.drugbank.com accessed 2021/01/25). *Predicted data (not measured)

\begin{tabular}{llll}
\hline Compound group & Example substance & $\log K_{\text {Ow }}$ & Water solubility \\
\hline
\end{tabular}

Pharmaceuticals

UV filters

Estrogens

Polar pesticides

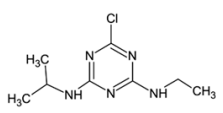

Simazine

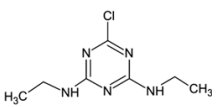

Carbamazepine<smiles></smiles>

Sulfamethoxazole (SMX)

$0.89^{\mathrm{a}}$<smiles>Cc1cc(NS(=O)(=O)c2ccc(N)cc2)no1</smiles>

$2.45^{\mathrm{a}}$

$18 \mathrm{mg} / \mathrm{L}\left(25^{\circ} \mathrm{C}\right)^{\mathrm{a}}$

2-Phenylbenzimidazole-5-sulfonic acid (PBSA)

$2^{\mathrm{a}, *}$

$317 \mathrm{mg} / \mathrm{L}^{\mathrm{d}, *}$<smiles>O=S(=O)(O)c1ccc2[nH]c(-c3ccccc3)nc2c1</smiles>

Octocrylene

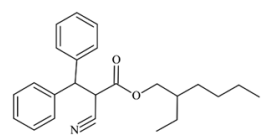

$7.1^{\mathrm{a}, \mathrm{c}}$

$6.1^{\mathrm{b}}$

Ethinylestradiol (EE2)

$3.67^{\mathrm{a}}$

$11.3 \mathrm{mg} / \mathrm{L}\left(27^{\circ} \mathrm{C}\right)^{\mathrm{a}}$

Estrone (E1)

$3.13^{\mathrm{a}}$

$0.03 \mathrm{mg} / \mathrm{L}\left(25^{\circ} \mathrm{C}\right)^{\mathrm{a}}$

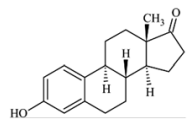

$33 \mathrm{mg} / \mathrm{L}\left(25^{\circ} \mathrm{C}\right)^{\mathrm{a}}$

$2.18^{\mathrm{a}}$

$6.2 \mathrm{mg} / \mathrm{L}\left(\mathrm{pH} 7,20^{\circ} \mathrm{C}\right)^{\mathrm{a}}$ 
Table 1 continued

\begin{tabular}{llll}
\hline Compound group & Example substance & $\log K_{\mathrm{OW}}$ & Water solubility \\
\hline Per- and polyfluoroalkyl substances & Perfluorooctane sulfonic acid (PFOS) & $4.49^{\mathrm{a}}$ & $3.2 \mu \mathrm{g} / \mathrm{L}\left(25{ }^{\circ} \mathrm{C}\right)^{\mathrm{a}}$ \\
Algal toxins & $1.7^{\mathrm{a}, \mathrm{c}}$ & $7 \mathrm{mg} / \mathrm{L}^{\mathrm{c}, *}$ \\
\end{tabular}

Table 2 Selected substances for this review and their current inclusion in MSFD/WFD and HELCOM assessments. For a current and full list of HELCOM core indicators, see https://helcom.fi/baltic-sea-trends/indicators/ ( ${ }^{a}$ removed from the updated watch list; n.a. not addressed)

\begin{tabular}{|c|c|c|c|c|}
\hline \multirow[t]{2}{*}{ Compound group } & \multicolumn{2}{|l|}{ WFD/MSFD } & \multicolumn{2}{|l|}{ HELCOM } \\
\hline & Substance & Inclusion & Indicator/index & Inclusion \\
\hline Pharmaceuticals & $\begin{array}{l}\text { Diclofenac }^{\mathrm{a}} \\
\text { Macrolide antibiotics } \\
\text { Amoxicillin } \\
\text { Ciprofloxacin }\end{array}$ & $\begin{array}{l}\text { Current or previous watch list of the } \\
\text { EQSD }\end{array}$ & Diclofenac & $\begin{array}{l}\text { Pre-core test } \\
\text { indicator } \\
1^{\circ} \text { Matrix: } \\
\text { seawater } \\
2^{\circ} \text { Matrix: biota }\end{array}$ \\
\hline UV filters & $\begin{array}{l}\text { 2-Ethylhexyl-4- } \\
\text { methoxycinnamat }^{\mathrm{a}}\end{array}$ & $\begin{array}{l}\text { Current or previous watch list of the } \\
\text { EQSD }\end{array}$ & n.a. & n.a. \\
\hline Estrogens & $\begin{array}{l}\text { Estrone }^{\mathrm{a}} \\
17 \alpha \text {-Ethinyl estradiol } \\
17 \beta \text {-Estradiol }\end{array}$ & $\begin{array}{l}\text { Current or previous watch list of the } \\
\text { EQSD }\end{array}$ & n.a. & n.a. \\
\hline Polar pesticides & $\begin{array}{l}\text { Simazine } \\
\text { Atrazine } \\
\text { Diuron } \\
\text { Isoproturon } \\
\text { Terbutryn }\end{array}$ & Priority substances of EQSD & n.a. & n.a. \\
\hline & $\begin{array}{l}\text { Methiocarb }^{\mathrm{a}} \\
\text { Neonicotinoids }^{\mathrm{a}}\end{array}$ & $\begin{array}{l}\text { Current or previous watch list of the } \\
\text { EQSD }\end{array}$ & n.a. & n.a. \\
\hline $\begin{array}{l}\text { Per- and polyfluoroalkyl } \\
\text { substances }\end{array}$ & PFOS & Priority substance of EQSD & PFOS & $\begin{array}{l}\text { Core indicator } \\
1^{\circ} \text { Matrix: biota } \\
2^{\circ} \text { Matrix: } \\
\text { seawater }\end{array}$ \\
\hline Algal toxins & n.a. & n.a. & $\begin{array}{l}\text { Cyanobacterial bloom } \\
\text { index }\end{array}$ & Pre-core indicator \\
\hline
\end{tabular}




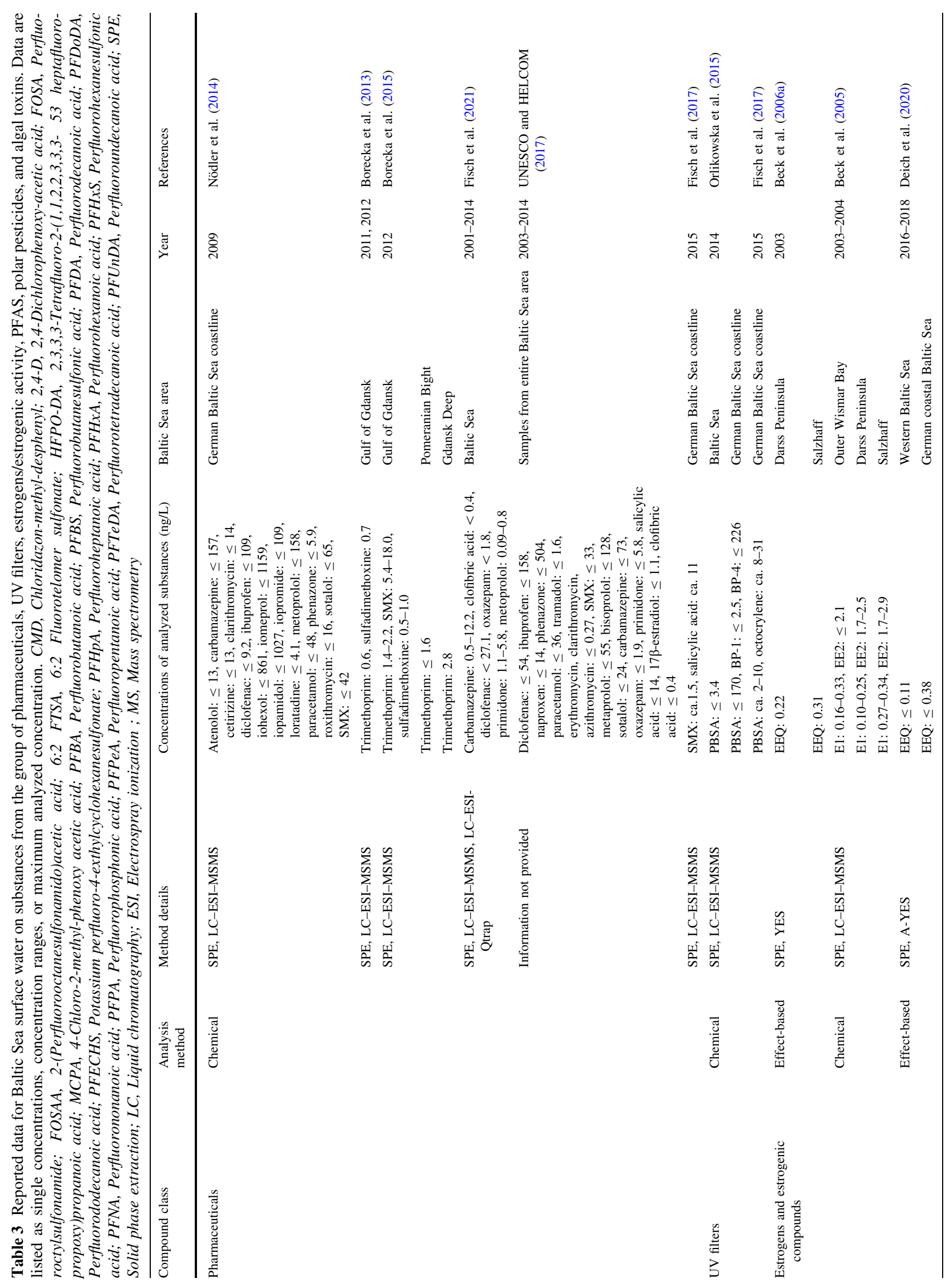

(C) The Author(s) 2021, corrected publication 2022 


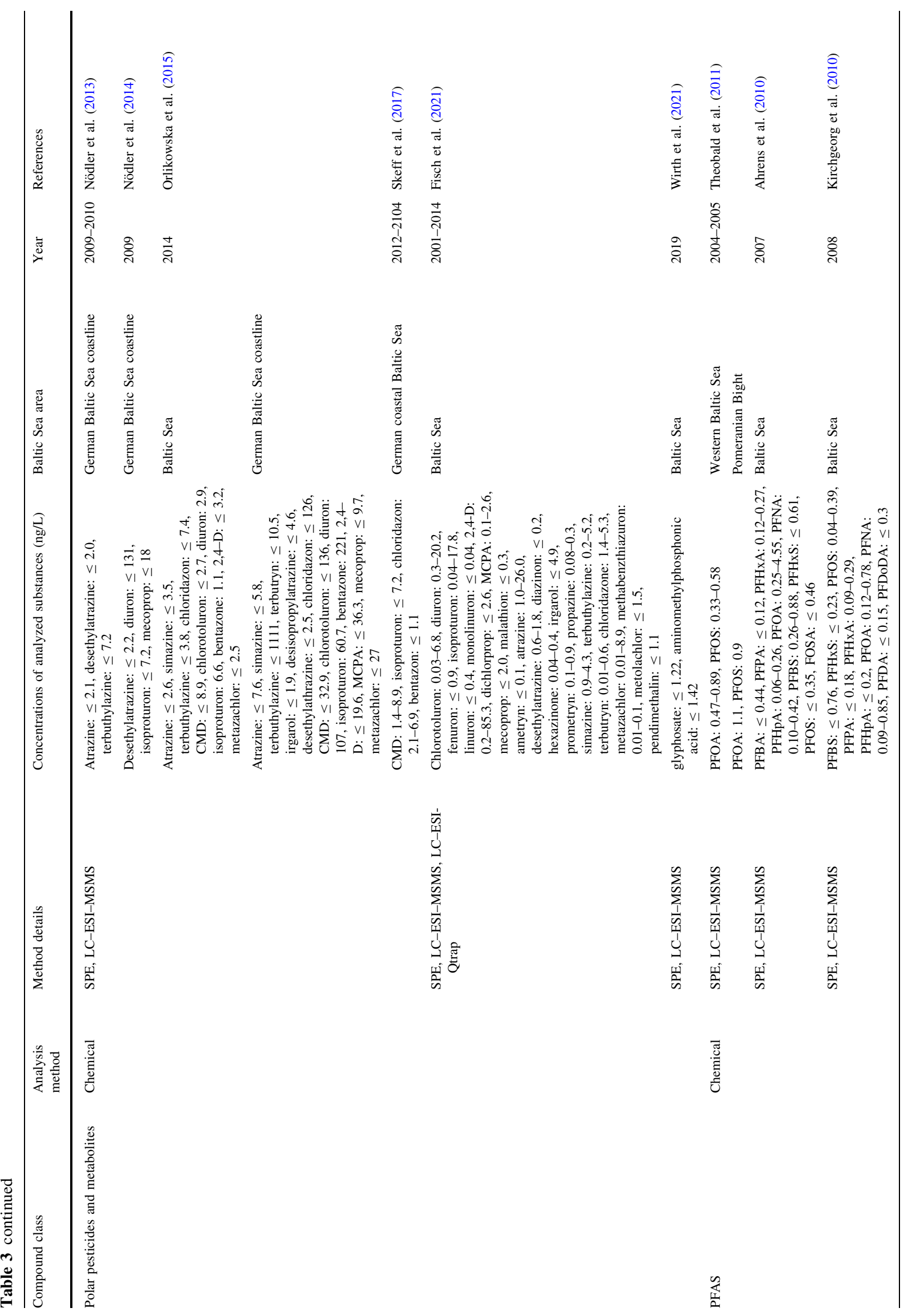




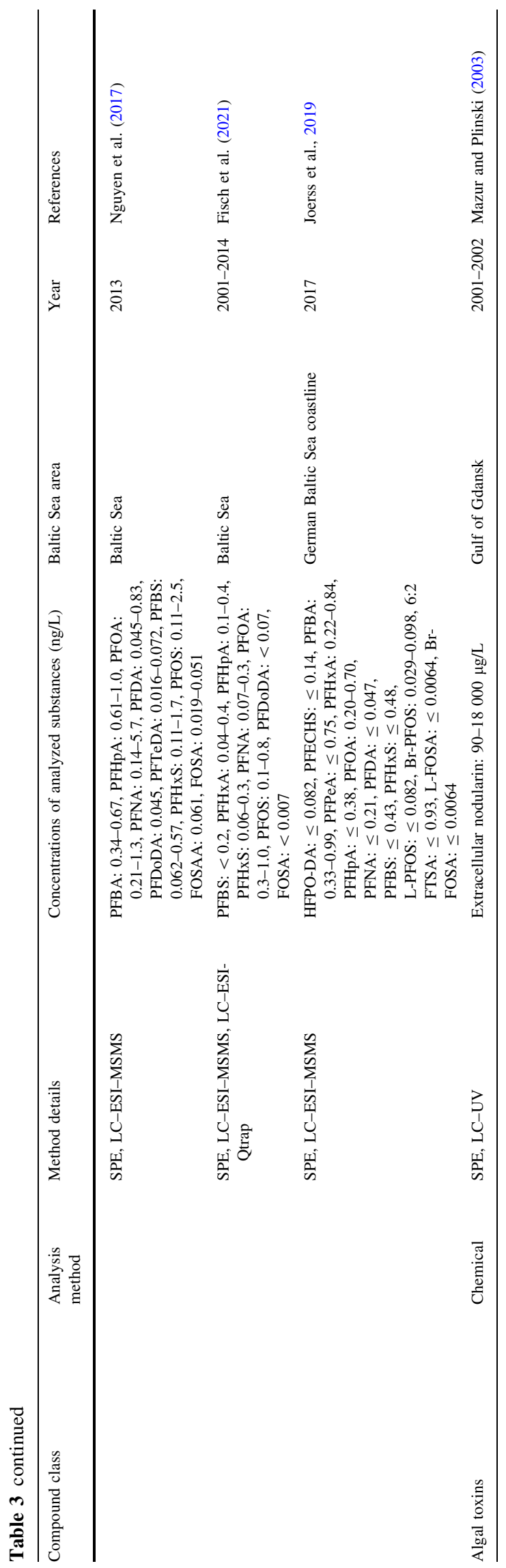

Common pharmaceutical substances analyzed in Baltic Sea surface water derive from the therapeutic groups of anti-inflammatory and analgesic agents, cardiovascular and central nervous system agents, antimicrobials, X-ray contrast media, and antiallergic agents. The compounds diclofenac, ibuprofen, paracetamol and phenazone, metoprolol, carbamazepine (Nödler et al. 2014; UNESCO and HELCOM 2017), sulfamethoxazole (SMX; Borecka et al. 2013, 2015; Nödler et al. 2014; Fisch et al. 2017; UNESCO and HELCOM 2017) as well as iopamidol and iomeprol (Nödler et al. 2014; Kötke et al. 2019) were the most frequently measured substances. In addition, Björlenius et al. (2018) conducted a Baltic Sea wide study on 93 pharmaceutical substances and detected 39 of them in surface water samples. Carbamazepine was the most frequently detected substance in that study.

UV filters are frequently included in personal care products such as sunscreen formulations or polymer-based products. The main source of UV filters into the marine environment is directly via recreational activities (DíazCruz and Barceló 2015). They are under ongoing investigation for being potentially persistent, bioaccumulative, and toxic in the environment (reviewed by Brausch and Rand 2011; Sánchez-Quiles and Tovar-Sánchez 2015). Endocrine disruptive effects were shown for the UV filter oxybenzone (Schlenk et al. 2005; Zwart et al. 2018). Due to their contribution to coral bleaching, the distribution of sunscreen formulations containing oxybenzone or octinoxate is banned in Hawaii to preserve the marine ecosystem (Hawaii Senate Bill 2571). Even though UV filters enter the environment mostly through the water phase, they can accumulate in different compartments such as sediments and biota (Sánchez-Quiles and Tovar-Sánchez 2015).

While UV filters were shown to be widely present in the marine environment (e.g., Rainieri et al. 2017), only few reports exist for the Baltic Sea (Orlikowska et al. 2015; Fisch et al. 2017; Apel et al. 2018). In Baltic Sea surface water, the UV filters 2-phenylbenzimidazole-5-sulfonic acid (PBSA), octocrylene, benzophenone (BP)-1, and BP-4 were detected, with PBSA and octocrylene as the most frequently detected compounds (Orlikowska et al. 2015; Fisch et al. 2017).

Estrogens and estrogenic compounds and their endocrine disruptive effects on organisms are largely in current focus of environmental and marine science (Hotchkiss et al. 2008; Arditsoglou and Voutsa 2012; Cotrim et al. 2016). The majority of the estrogenic activity in the environment presumably derives from naturally occurring and synthetic estrogens such as estrone (E1), 17 $\beta$-estradiol (E2), the anthropogenic $17 \alpha$-ethinyl estradiol (EE2), and estriol (Jarošová et al. 2014). This subject is often addressed through chemical analysis of estrogenic 
compounds, but also through the assessment of effects that are specific to estrogenic pressure and expressed as estradiol equivalent concentrations (EEQ). In the Baltic Sea, studies were mainly conducted at coastal sites and estrogen concentrations as well as estrogenic effects were determined (Beck et al. 2005, 2006a,b; Deich et al. 2020). Overall, E1 and EE2 are the predominant estrogens in Baltic Sea surface water (Beck et al. 2005, 2006b).

Widespread and large application of pesticides in industrial cropping and agriculture, domestic use, and other fields of application is of environmental concern due to the adverse effects they might have on non-target species. Compounds in current focus of environmental research belong to the group of polar pesticides such as triazines (e.g., atrazine and simazine), phenoxyacid herbicides [e.g., mecoprop and 2,4-dichlorophenoxy-acetic acid (2,4-D)], urea herbicides (e.g., diuron and chlorotoluron), or neonicotinoids (e.g., imidacloprid). Data on the occurrence of polar pesticides in surface water of the Baltic Sea and its coast in recent years were reported by Nödler et al. (2013, Nödler et al. 2014), Orlikowska et al. (2015), Skeff et al. (2017), and Fisch et al. (2021) and the most frequently addressed substances were diuron and isoproturon.

Per- and polyfluoroalkyl substances (PFAS) are utilized for technical applications such as fire extinguishing agents and the production of water and oil-repellent coatings. PFAS and their metabolites are known for their toxicity towards biota (DeWitt 2015). The PFAS compounds perfluorooctane sulfonate (PFOS) and perfluorooctanoic acid (PFOA) are internationally restricted under the Stockholm Convention. However, regulation of this compound class is exceptionally challenging due to the huge number of individual substances and new, structurally similar PFAS constantly entering the market. Therefore, the degree of environmental contamination by this compound class is currently not fully understood (Wang et al. 2017).

A mass balance performed by Filipovic et al. (2013) for selected PFAS compounds showed that riverine inflow and atmospheric deposition are predominant sources of PFAS to the Baltic Sea and a range of long-chain and short-chain PFAS were detected in Baltic Sea surface water (Ahrens et al. 2010; Kirchgeorg et al. 2010; Theobald et al. 2011; Nguyen et al. 2017; Joerss et al. 2019; Fisch et al. 2021). However, Johansson and Underman (2020) pointed out that based on studies applying methods to detect total extractable fluorine, the so far known PFAS compounds probably represent only $10-40 \%$ of total PFAS in environmental matrices.

Naturally produced algal toxins are of concern for the Baltic Sea due to the increased frequency, biomass and duration of harmful blooms of cyanobacteria and filamentous algae (e.g., Finni et al. 2001). The HELCOM holistic assessment from 2018 showed that the cyanobacterial bloom index failed in all assessed areas (HELCOM 2018a). The presence of cyanotoxins such as the hepatotoxin nodularin, polybrominated phenols such as tribromophenols, hydroxyl- and methoxylated polybrominated diphenyl ethers (OH-and MeO-PBDEs), and polybrominated dibenzodioxins has been confirmed in all compartments of the Baltic Sea food web, from primary producers such as algae and bacteria (Malmvärn et al. 2008), to mussels, fish (Sipiä et al. 2007; Löfstrand et al. 2011), seals (Routti et al. 2009; Lindqvist and Asplund 2019), and birds (Sipiä et al. 2008; Nordlöf et al. 2012). Metabolic transformation processes of the PBDEs ultimately lead to the accumulation of the most toxic congener 6-OH-BDE47 at the top of the food chain (Dahlgren et al. 2016). Concentration fluctuations by three orders of magnitude within a few weeks have been observed in blue mussel (Mytilus edulis) (Löfstrand et al. 2011) and the filamentous algae Ceramium tenuicorne (Dahlgren et al. 2016). In Baltic Sea studies, extracellular and cell-bound nodularin analysis was conducted in seawater following blooms of the cyanobacterium $\mathrm{No}$ dularia spumigena, showing large variations in nodularin concentration in the water column along with a high turnover rate (Mazur and Plinski 2003; Carlsson and Rita 2019). These properties render the naturally produced toxins complicated to fit into the framework of national monitoring programs, for which sampling are often conducted in longer intervals.

\section{ADVANCES AND STATE-OF-THE-ART METHODS FOR CHEMICAL ANALYSIS OF THE SELECTED COMPOUND GROUPS IN SEAWATER}

\section{Methods for seawater sample processing}

Compared to many of the legacy contaminants, several of the herein addressed substances are characterized by lower $\log K_{\mathrm{OW}}$ values, which imply a higher polarity of these substances. Hence, many of them possess substantial water solubility (Table 1), which can be the main obstacle in sample preparation and instrumental analysis. The comparably low concentrations in the marine environment usually require sample enrichment during sample preparation.

Large-volume injection of up to $5 \mathrm{~mL}$ was established in LC-MS(MS) analysis as a way to overcome low concentrations in environmental water samples and to replace preenrichment steps, e.g., during the analysis of pesticides and pharmaceuticals (reviewed by Busetti et al. 2012). Dispersive liquid-liquid microextraction was used for the preconcentration of samples for the analysis of UV filters (Benedé et al. 2014) or PFAS (Concha-Graña et al. 2018) 
in seawater. However, if higher enrichment factors are required, solid phase extraction (SPE) is the method of choice for UV filters (Bratkovics and Sapozhnikova 2011), pharmaceuticals (Paíga et al. 2015; Białk-Bielińska et al. 2016), pesticides (Loos et al. 2013; Rodríguez-González et al. 2017; Li et al. 2019; Xiao et al. 2021), estrogens (Rocha et al. 2012; Ronan and McHugh 2013; Heub et al. 2015), and PFAS (Loos et al. 2013; Brumovský et al. 2018). Besides classical off-line SPE approaches, automated procedures directly coupled to LC systems have been utilized in the last years, e.g., for the analysis of UV filters in seawater samples (Oliveira et al. 2010; Montesdeoca-Esponda et al. 2012), triazine herbicides (RodríguezGonzález et al. 2016), and algal toxins (Zhang et al. 2018; Merlo et al. 2020; Wang et al. 2021).

Recently, a group of resins have become available which base on the target analytes' specific molecular recognition sites and, therefore, allow a highly selective sample extraction and sample enrichment (Ansari and Karimi 2017). Those tailor-made molecularly imprinted polymers were, for example, successfully utilized for the analysis of the antibiotic sulfadiazine (Lian et al. 2014) and the herbicide glyphosate in Baltic Sea water (Wirth et al. 2021).

In view of the water solubility of the target analytes, finding a suitable SPE material can be challenging, particularly, if the target analyte has ionic characteristics. In this case, the application to seawater is largely restricted, as sea salt will bind to the binding sites of the SPE resin, avoiding efficient retention of the target analyte onto the column. In this regard, it has recently been shown that electrodialysis (ED) is a promising sample processing tool for the targeted analysis of pollutants from seawater (Wirth et al. 2019, 2021; Lohrer et al. 2020). ED is established in many industrial processes, e.g., for seawater desalination during drinking water production, but has found limited application in environmental sciences, so far. ED can be used to reduce the sample salinity prior to further sample processing and analysis. Improving effects such as enhanced sensitivity during mass spectrometric (MS) analysis could be shown (Wirth et al. 2019). However, analytes can be lost from samples via ED membrane passage or system wall adsorption. In a detailed investigation on the recovery of a wide polarity range of target pollutants, compounds of medium polarity ( $\log K_{\mathrm{OW}}-1$ to 3 ) were found to have especially high recoveries after the desalination process. Furthermore, compounds of high polarity $\left(\log K_{\mathrm{OW}}<-1\right)$, e.g., the herbicide glyphosate, were found to only have decreased recoveries at low residual salinities. Thus, such compounds are also suitable for ED-based sample preparation, as long as ED is terminated before significant loss occurs and the subsequent analytical procedure tolerates the residual salt content.

\section{Analytical approaches}

Chromatographic separation through LC is analytically very versatile and it is currently the predominant separation technique for the herein addressed substances due to their hydrophilic properties (Wille et al. 2012; Noguera-Oviedo and Aga 2016). However, with LC--MS(MS)-based methods, matrix effects may emerge and should be carefully evaluated, in particular, if ionization is conducted with electrospray ionization (ESI; Busetti et al. 2012; Magi and Di Carro 2018).

MS methods are still the method of choice for qualitative and quantitative analysis (Magi and Di Carro 2018). Within the last decades, MS sensitivity was enhanced considerably: Detection levels for triple quadrupole tandem mass spectrometers (MSMS) have been reduced to subfemtogram on column level, and simultaneous increase in scan rates allows analysis of an increased number of target compounds; hence multi-class methods with up to 1000 multiple-reaction monitoring (MRM) transitions within a single chromatography run are not uncommon anymore (Wille et al. 2012; Sulyok et al. 2020). Compared to single quadrupole technology, routine application of MRM transitions per analyte has enhanced selectivity and identification via the detection of a number of fragment ions next to the quasi-molecule ion. However, tandem mass spectrometry with preselected MRM transitions reduces the analysis to preselected targets.

High-resolution mass spectrometry (HR-MS), e.g., timeof-flight (TOF) or Orbitrap analyzers allow the determination of exact mass combined with high resolving power. Increased resolving power enables the analysis of lower analyte concentrations in more complex matrices with enhanced mass selectivity (Leendert et al. 2015). To date, TOF mass analyzers attain mass resolving power of 50000 or higher, while Orbitrap systems can reach a resolving power above 1000000 (e.g., Schmidt et al. 2018). Additional fragmentation $\left(\mathrm{MS}^{\mathrm{n}}\right)$ makes both analyzers more selective than accurate-mass detectors alone (Zubarev and Makarov 2013). Hence, today, most TOF and Orbitrap analyzers are employed in hybrid with a quadrupole or ion trap, rather than in stand-alone configuration (Maurer and Meyer 2016).

High-resolution continuum molecular absorption spectrometry was used for the complex field of fluorinated organic compounds, which also includes the group of PFAS (Metzger et al. 2019). Instead of the typical target analysis, this approach yields a quantitative value for the sum of extractable organically bound fluorine in an environmental sample, which mostly has anthropogenic origin. 
In combination with SPE, the developed method was utilized for a screening in riverine surface water with detection limits in the low ng/L range. Akhdhar et al. (2020) showed that this approach might also be applicable to marine surface water analysis.

Non-targeted and suspect analysis approaches are gaining increasing interest, as known chemicals comprise only a small proportion of the contaminant mixture in the environment. Also in water policy this approach is considered supportive for the detection and identification of emerging contaminants (Leendert et al. 2015; Hollender et al. 2019). Fourier-transform ion cyclotron resonance mass spectrometry and Orbitrap instruments, but also untargeted MSMS have been applied across terrestrial and marine environments to decipher the biogeochemical cycling of carbon compounds (e.g., Longnecker and Kujawinski 2017). These analytical approaches equally enable the study of the anthropogenic chemical load in the environment. TOF-MS in combination with a molecular feature extraction algorithm was used in suspect analysis for the identification of the so far unknown PFAS compounds in river water (Strynar et al. 2015) while a hybrid Orbitrap-HRMS was used for seawater (Concha-Graña et al. 2018). Thus, for the identification of unknown PFAS, in particular, HRMS has become indispensable (Gao et al. 2020). A combination of untargeted and targeted screening of the sample to detect new emerging contaminants and their transformation products can also provide security in production processes (Hogenboom et al. 2009). In the marine environment, untargeted screening revealed the presence of pharmaceuticals, personal care products, and pesticides via LC-Orbitrap-HRMS in the Belgian North Sea in trace amounts (Vanryckeghem et al. 2019). Using untargeted HRMS, Lara-Martín et al. (2020) identified more than 500 sewage-derived contaminants in the NE Atlantic and could trace the anthropogenic imprint beyond the continental margin. Even in the sensitive Antarctic ecosystem, the analysis of algal metabolomes via FT-ICRMS revealed the presence of several persistent and pharmaceutical compounds (Duarte et al. 2021).

The complex matrix of seawater might hamper the detection of contaminants due to the high risk of falsepositive signals from compounds of the same exact mass. Currently, only the combination of different analytical approaches such as HR-MS, MSMS, and NMR can provide the necessary level of confirmation (Agüera et al. 2013; Ruan and Jiang 2017), but the unambiguous identification of compounds remains difficult due to the limitation of spectral and structure library coverage. Schymanski et al. (2014) communicated a level system on identification confidence in HR-MS analysis, which is widely followed in the community. Online databases or tools such as massbank or GNPS (Horai et al. 2010; Wang et al. 2016) are growing and allow for meta- or re-analysis of datasets as the database entries increase.

\section{Passive (integrative) sampling}

The free dissolved concentration of a compound is important for the evaluation of its bioavailability to predict toxic effects and accumulation in the food web. The fraction of the free dissolved concentration of trace substances in water can only be determined with passive sampling. During passive sampling, trace substances adsorb on suitable materials and are concentrated onto the sampler from the surrounding medium. Extraction of the adsorbed substances from the sampler and their target or non-target/suspect analysis is conducted according to their chemical characteristics and the overall aim of the integrative sampling.

Adsorption of contaminants onto the sampler is time dependent and, thus, passive sampling provides integrated results over a period of exposure time (Smedes and Booij 2012). Physicochemical principles of passive sampling have been investigated in detail and evaluated in field and laboratory studies (Booij et al. 2007; Smedes et al. 2009; Morin et al. 2018). Required exposure times to collect sufficient amount of the substance primarily depend on the target substance and range from several days for substances with $\log K_{\mathrm{OW}}$ of approx. 4 up to years with $\log K_{\mathrm{OW}}>7$ (Booij et al. 2016). However, exposure to a sampler is not unlimited due to disturbing effects such as biofouling or changing environmental conditions.

Passive sampling devices have been developed for a range of applications in seawater (reviewed by e.g., Namieśnik et al. 2005; Vrana et al. 2005; Taylor et al. 2019), however, mostly for non-polar organic contaminants (e.g., Lohmann et al. 2012), but also for algal toxins (e.g., Li et al. 2011; Zendong et al. 2016). However, the polar organic chemical integrative sampler (POCIS) has been successfully applied to pharmaceuticals, estrogens, and polar pesticides down to the low ng/L range in marine waters (Martínez Bueno et al. 2016; Jones et al. 2019).

\section{ASSESSMENT OF EFFECTS}

Adverse effects of contaminant exposures can be assessed by different effect-based methods, such as in situ studies on field-collected organisms, caging studies in polluted sites as well as laboratory exposure studies using in vitro and in vivo bioassays. Advantages of in situ monitoring include assessment of effects reflecting true environmental conditions such as (life)long exposure to hazardous substances, bioavailability of pollutants, and the presence of chemical mixtures. A challenge is to link observed effect to a 
specific chemical. In contrast, in vitro and in vivo exposure studies are performed under highly controlled experimental settings, which increase their reproducibility. Despite low ecological relevance, many bioassays are considered valuable screening tools in risk assessment and a complement to field-based in situ monitoring or an entirely chemical monitoring approach (Wernersson et al. 2014, 2015; Carere et al. draft).

In situ field monitoring uses biomarkers to assess the toxicological effects of exposure to hazardous substances from the molecular, cellular, and physiological level to higher biological levels such as reproduction disorders and signs of disease in field-sampled organisms (reviewed by e.g., Lionetto et al. 2021). Biomarkers are considered as either "specific" or "general" depending on their specificity in response. Specific biomarkers respond to either certain substances, such as imposex induced by tributyltin, or a group of substances with similar mode of action, such as estrogenic substances or certain groups of pesticides, like imidacloprid inhibiting the acetylcholine esterase activity (AChE) or terbutryn, simazine, diuron, and atrazine inhibiting the photosystem II (PSII). In contrast, general biomarkers such as lysosomal membrane stability (LMS), liver histopathology, or fish disease index respond to several classes of chemicals, but can also respond to other environmental stressors. They often reflect a more general stress response such as genetic and cellular damage, histological alterations, and early life stage effects.

For the in vitro bioassays, a battery of mostly high throughput screening assays are established for the assessment of specific biological effects using cellular systems of reporter gene assays in addition to cellular response assays. These bioassays are tailor-made to assess effects such as various types of endocrine disruption, genotoxicity, cytotoxicity, oxidative stress or metabolic enzyme activation, and several other endpoints of relevance to the aquatic environment. In vitro bioassays that measure estrogenic effects would, thus, target substances such as EE2, E2, and E1, but also weaker estrogens such as nonylphenols. Correspondingly, in vitro bioassays measuring thyroid-transthyretin disruption (TTR-TR $\beta$ CALUX) would target several PFAS compounds, but also chlorinated paraffins (Sprengel et al. 2021).

By using short-term toxicity tests on whole organisms, in vivo bioassays are designed to assess effects such as algae growth, Daphnia immobilization or fish embryo vitality (Escher et al. 2014; Di Paolo et al. 2016; Neale et al. 2017) and are used to assess the response to exposure to a variety of chemicals.

The combination of passive sampling and effect-based analysis was reported by De Baat et al. (2019) who developed a surface water assessment strategy utilizing in situ field exposure tests as well as in vitro and in vivo bioassays to POCIS passive sampler extracts and by Moeris et al. (2021) who combined passive sampler seawater extracts with an in vivo bioassay using Phaeodactylum tricornutum. In a recent European inventory and assessment of more than 130 effect-based methods for toxic substances, the authors conclude that at least ten marine biomarkers can now be considered "mature" from a WFD and MSFD perspective and could be used to assess ecologically relevant effects of chemical mixtures (Carere et al. draft). Standard Operating Procedures, environmental assessment criteria as well as national monitoring programs exist. For others, the main issue that remains to be solved before use in a regulatory context is the availability of assessment criteria.

However, specific biomarkers and bioassays for the herein addressed compounds have so far primarily been developed and used for estrogens and estrogenic substances. Estrogenicity-specific biomarkers include the aberrant production of the egg yolk protein vitellogenin (VTG) and the presence of ovarian tissue in fish testis, socalled intersex. The in vitro bioassays ER-CALUX (Estrogen receptor-mediated, chemical-activated luciferase reporter gene expression) and YES (Yeast estrogen screen) are frequently applied to detect estrogenicity and Carere et al. (draft) conclude that such in vitro tests can now be considered mature enough to be considered in a WFD context, also presenting an approach on how to develop assessment criteria ("trigger values"). Hettwer et al. (2018) reported on the Arxula-yeast estrogen screen (A-YES) which is also applicable to saline water. However, for marine samples, sample enrichment is usually required, as achievable test detection limits are else often above the trigger value. Thus, YES testing in combination with SPE in surface water samples from the Baltic Sea was reported by Beck et al. (2006a) and Deich et al. (2020) (Table 3). However, both reported on the suppression of yeast growth, presumably as a result of high concentrations of estrogenically active compounds in the extracts and it was considered that those could also derive from the sample enrichment. Thus, less intense solid phase extraction in combination with a more sensitive in vitro bioassay such as the ER-CALUX might be an alternative to overcome generally very low marine concentrations.

\section{COMBINED TECHNIQUES: EFFECT-DIRECTED ANALYSIS (EDA)}

Effect-directed analysis (EDA) uses an integrated approach where bioassays are combined with sample fractionation to reduce sample complexity followed by chemical analysis (reviewed by Brack et al. 2016; Hong et al. 2016). This process is repeated until the chemicals responsible for the 
observed effect in a specific bioassay are identified. The EDA approach, therefore, aids in identifying the drivers of toxicity in the chemical mixtures often found in aquatic environments such as the Baltic Sea. The fractionation procedure in EDA uses different chromatography techniques separating chemicals according to their properties. Identification of toxic compounds in individual fractions is mainly performed using targeted, but also non-targeted or suspect MS methods (Hollender et al. 2019). For example, Brennan et al. (2020) proposed a strategy to design EDA for the analysis of endocrine-active compounds in water in combination with liquid chromatography (LC)-based fractionation and mass spectrometric analysis and Tufi et al. (2016) reported on the identification of AChE inhibitors in surface water through an EDA approach.

Despite an increasing use of EDA, relatively few studies have been performed on seawater extracts so far. However, Beck et al. (2006b) applied a fractionation technique based on reverse-phase chromatographic separation in combination with YES testing and chemical analysis to detect different types of estrogens and estrogenic mimicking compounds contributing to the estrogenic activity found in surface water samples from the German Baltic Sea coast. In addition, by using EDA, Booij et al. (2015) identified six herbicides in Dutch estuarine and coastal waters responsible for the inhibition of photosystem efficiency in marine microalgae. Finally, in an EDA approach, the estrogenic effect of the UV filter oxybenzone was identified (Schlenk et al. 2005; Zwart et al. 2018).

\section{SYNTHESIS UND RECOMMENDATIONS FOR IMPROVED ASSESSMENT OF THE STATE OF THE BALTIC SEA}

Negative effects on marine organisms to varying degree can result from the presence of the substances in focus of this review. There is a vast number of approaches to derive information on the presence of these compounds in the marine environment. They can be divided into methods of chemical analysis and those assessing an effect. State-ofthe-art methods are presented herein; however, the different approaches provide diverse information with different significance for interpreting the impact of individual toxic chemicals and mixtures thereof on the marine environment (Fig. 2).

Contaminants of emerging concern are currently only partially addressed in the monitoring of the Baltic Sea. A broader involvement of the substances from the groups of pharmaceuticals, estrogenic compounds, UV filters, and polar pesticides in HELCOM programs, including the establishment of threshold values, will enable the consideration of their associated risks in the holistic assessment of the Baltic Sea. In addition to that, their chemical

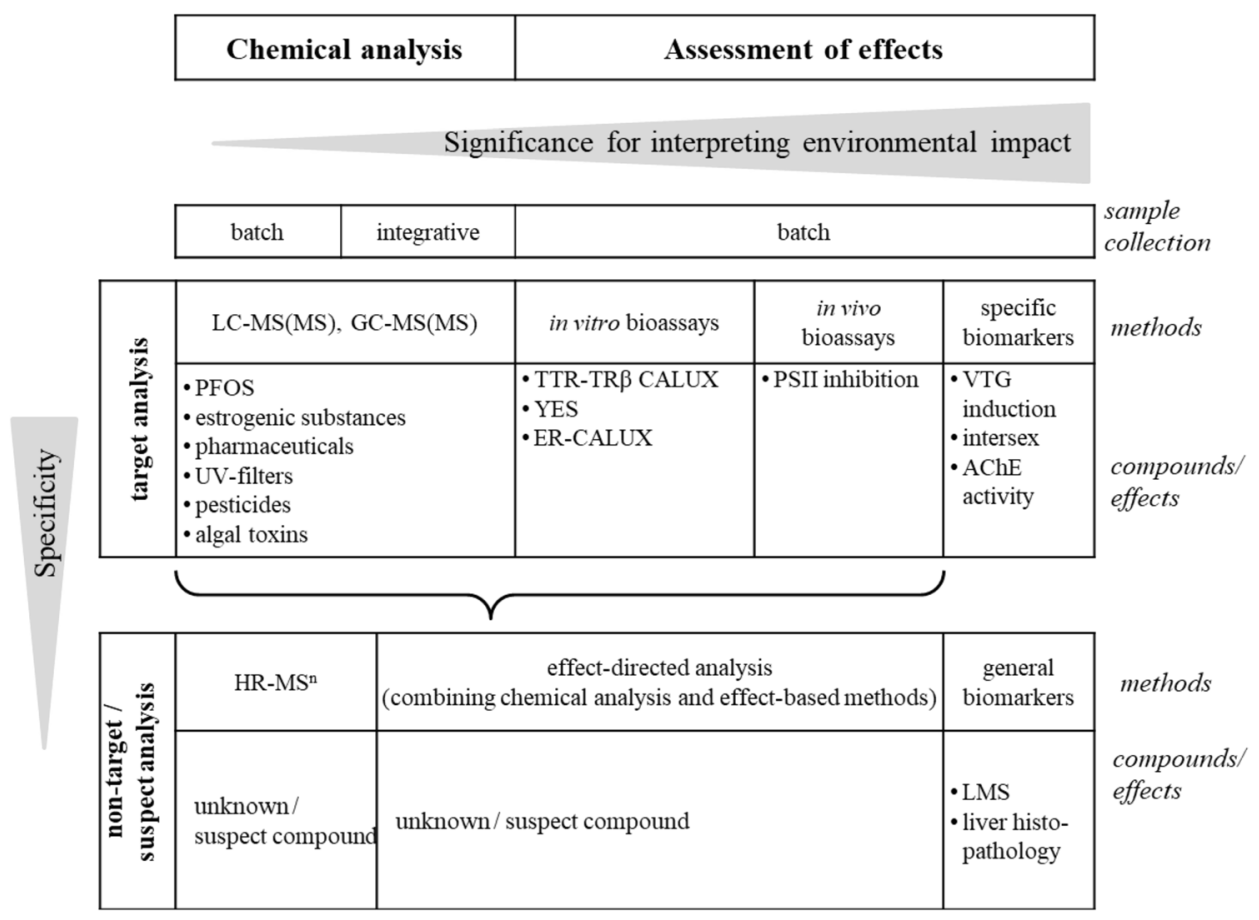

Fig. 2 Overview and classification of example methods and compounds/effects utilized in chemical analysis as well as assessment of effects for the analysis of compounds of emerging concern in the Baltic Sea. Sample collection in "batch" corresponds to sampling at one time, while "integrative" is the sampling over a certain time period (passive sampling) 
monitoring in seawater allows tracing the potential sources and paths into the Baltic Sea. Naturally produced algal toxins are currently not addressed in any Baltic Sea water policy context. Investigations on peak concentrations of these toxins would benefit from data collection on a weekly basis during a season with high biological activity. The spatiotemporal variations of the toxin concentrations render sessile, bottom dwelling filter feeders such as blue mussels suitable matrices for sampling for monitoring purposes. These organisms are especially exposed to algal toxins and other contaminants, as they accumulate high amounts of dissolved and particulate substances from the water column in combination with the fact that many filamentous algae are epiphytic on mussels and release chemical compounds during senescence and decay. Studies investigating concentrations and effects on higher organisms benefit from including a sum of the two groups $\mathrm{MeO}-$ PBDEs and OH-PBDEs.

Data on the free dissolved fraction of a compound obtained through passive (integrative) sampling could further substantiate determined seawater concentrations. This provides additional information on the compounds' bioavailability and potential toxicity to organisms. Nonetheless, only effect-based methods provide a direct measure of current impact. Methods addressing effects that derive specifically from the herein addressed compounds are currently not implemented in HELCOM monitoring and are not mandatory in the WFD/MSFD context. The effect-based approach would fit very well into the HELCOM monitoring context, to cover substances not yet listed and the effects of mixtures of toxic substances. Assessment procedures and criteria are now available to cover at least the presence of estrogenic substances in surface waters and in vitro tests that measure thyroid disruption could be considered to at least partially cover some PFAS compounds.

Overall, chemical analysis alone will not provide sufficient information to assess the risks for marine organisms and, furthermore, cannot cover all substances. In this regard, it was shown for water samples from different sources, that the known effects of the therein detected chemicals could explain less than $0.1 \%$ of the observed induction of the oxidative stress response measured by an in vitro bioassay (Escher et al. 2013). Thus, it must be considered that unknown compounds present in the water largely contribute to toxic effects, which underlines the need for effect-based analysis for an efficient assessment. However, sole assessment of effects will also not provide enough information on the presence of individual substances or local and temporal trends of contaminant concentrations in the Baltic Sea. Thus, combining results from chemical analysis approaches with those from effect-based methods provide a clearer picture of the environmental risks that might derive from concentrations of contaminants and naturally produced toxins. For instance, a weight-of-evidence approach is widely used for the assessment of sediment sites. The sediment quality triad (Chapman 1990) integrates results from chemical analysis, toxicity testing, and in situ field monitoring to assess the potential risk that might derive from contaminated sediments. In addition, the International Council for the Exploration of the Sea (ICES) has produced detailed reports on integrated monitoring of contaminants and their effects (Davies and Vethaak 2012). This concept could be adapted towards seawater and would aid in determining the current state of the Baltic Sea.

\section{CONCLUSIONS}

Pressure on Baltic Sea organisms arises from anthropogenically and naturally derived harmful substances. Negative effects to marine organisms can derive from substances of the compound groups pharmaceuticals, estrogenic compounds, UV filters, polar pesticides, and naturally produced algal toxins. Herein, we conducted literature searches, basically following the systematic literature review technique described by Mengist et al. (2020), on concentrations of substances of these compound classes in the Baltic Sea and on methodological advances for their chemical and effect-based analysis suitable for marine water. Our data review shows that individual substances of these compound groups are present in Baltic Sea water. However, they are currently hardly addressed in HELCOM or WFD/MSFD monitoring, meaning that associated risks are not taken into account in the holistic assessment of the state of the Baltic Sea.

The very low compound concentrations typical for marine waters, in combination with their chemical characteristics, require sensitive and robust methods and instrumentation for their analysis. Advances in the field of selective analyte enrichment from saline water as well as instrumental developments in the field of mass spectrometric techniques set the basis for the efficient, highly sensitive, and selective analysis in seawater. Apart from the mere chemical analysis, there is the need to include results from effect-based methods into the assessment to derive current impact of individual substances and compound mixtures on marine organisms. In this regard, a range of biomarkers and bioassays have already been developed for operational use in marine waters. The complementary use of different methodologies pointing towards different aspects of pressure might be a promising path for future contaminant and risk assessment in the Baltic Sea. 
Acknowledgements BONUS SEAM has received funding from BONUS (Art. 185), funded jointly by the EU, the Swedish Research Council Formas and the Estonian Research Council. The authors are grateful to Dr. Barbara Hentzsch for support during the writing of the article.

Funding Open Access funding enabled and organized by Projekt DEAL.

Open Access This article is licensed under a Creative Commons Attribution 4.0 International License, which permits use, sharing, adaptation, distribution and reproduction in any medium or format, as long as you give appropriate credit to the original author(s) and the source, provide a link to the Creative Commons licence, and indicate if changes were made. The images or other third party material in this article are included in the article's Creative Commons licence, unless indicated otherwise in a credit line to the material. If material is not included in the article's Creative Commons licence and your intended use is not permitted by statutory regulation or exceeds the permitted use, you will need to obtain permission directly from the copyright holder. To view a copy of this licence, visit http://creativecommons. org/licenses/by/4.0/

\section{REFERENCES}

Agüera, A., M.J. Martínez Bueno, and A.R. Fernández-Alba. 2013. New trends in the analytical determination of emerging contaminants and their transformation products in environmental waters. Environmental Science and Pollution Research 20: 3496-3515. https://doi.org/10.1007/s11356-013-1586-0.

Ahrens, L., W. Gerwinski, N. Theobald, and R. Ebinghaus. 2010. Sources of polyfluoroalkyl compounds in the North Sea, Baltic Sea and Norwegian Sea: Evidence from their spatial distribution in surface water. Marine Pollution Bulletin 60: 255-260. https:// doi.org/10.1016/j.marpolbul.2009.09.013.

Akhdhar, A., M. Schneider, A. Orme, L. Schultes, A. Raab, E.M. Krupp, J.P. Benskin, B. Welz, et al. 2020. The use of high resolution graphite furnace molecular absorption spectrometry (HR-MAS) for total fluorine determination in extractable organofluorines (EOF). Talanta 209: 120466. https://doi.org/10.1016/j.talanta.2019.120466.

Alygizakis, N.A., P. Gago-Ferrero, V.L. Borova, A. Pavlidou, I. Hatzianestis, and N.S. Thomaidis. 2016. Occurrence and spatial distribution of 158 pharmaceuticals, drugs of abuse and related metabolites in offshore seawater. Science of the Total Environment 541: 1097-1105. https://doi.org/10.1016/j.scitotenv.2015.09.145.

Ansari, S., and M. Karimi. 2017. Novel developments and trends of analytical methods for drug analysis in biological and environmental samples by molecularly imprinted polymers. Trends in Analytical Chemistry 89: 146-162. https://doi.org/10.1016/j.trac. 2017.02.002.

Apel, C., H. Joerss, and R. Ebinghaus. 2018. Environmental occurrence and hazard of organic UV stabilizers and UV filters in the sediment of European North and Baltic Seas. Chemosphere 212: 254-261. https://doi.org/10.1016/j.chemosphere. 2018.08.105.

Arditsoglou, A., and D. Voutsa. 2012. Occurrence and partitioning of endocrine-disrupting compounds in the marine environment of Thermaikos Gulf, Northern Aegean Sea, Greece. Marine Pollution Bulletin 64: 2443-2452. https://doi.org/10.1016/j.marpolbul. 2012.07.048
Beck, I.-C., R. Bruhn, J. Gandrass, and W. Ruck. 2005. Liquid chromatography-tandem mass spectrometry analysis of estrogenic compounds in coastal surface water of the Baltic Sea. Journal of Chromatography A 1090: 98-106. https://doi.org/10. 1016/j.chroma.2005.07.013.

Beck, I.-C., R. Bruhn, and J. Gandrass. 2006a. Analysis of estrogenic activity in coastal surface waters of the Baltic Sea using the yeast estrogen screen. Chemosphere 63: 1870-1878. https://doi.org/10. 1016/j.chemosphere.2005.10.022.

Beck, I.-C., R. Bruhn, and J. Gandrass. 2006b. Bioassay-directed fractionation for analyzing estrogens in surface waters of the German Baltic Sea. Acta Hydrochimica et Hydrobiologica 34: 560-567. https://doi.org/10.1002/aheh.200600654.

Benedé, J.L., A. Chisvert, A. Salvador, D. Sánchez-Quiles, and A. Tovar-Sánchez. 2014. Determination of UV filters in both soluble and particulate fractions of seawaters by dispersive liquid-liquid microextraction followed by gas chromatographymass spectrometry. Analytica Chimica Acta 812: 50-58. https:// doi.org/10.1016/j.aca.2013.12.033.

Białk-Bielińska, A., J. Kumirska, M. Borecka, M. Caban, M. Paszkiewicz, K. Pazdro, and P. Stepnowski. 2016. Selected analytical challenges in the determination of pharmaceuticals in drinking/marine waters and soil/sediment samples. Journal of Pharmaceutical and Biomedical Analysis 121: 271-296. https:// doi.org/10.1016/j.jpba.2016.01.016.

Björlenius, B., M. Ripszám, P. Haglund, R.H. Lindberg, M. Tysklind, and J. Fick. 2018. Pharmaceutical residues are widespread in Baltic Sea coastal and offshore waters-Screening for pharmaceuticals and modelling of environmental concentrations of carbamazepine. Science of the Total Environment 633: 1496-1509. https://doi.org/10.1016/j.scitotenv.2018.03.276.

Booij, K., B. Vrana, and J.N. Huckins. 2007. Chapter 7: Theory, modelling and calibration of passive samplers used in water monitoring. In Passive sampling techniques in environmental monitoring, ed. R. Greenwood, G. Millis, and B Vrana, 141-169. https://doi.org/10.1016/S0166-526X(06)48007-7.

Booij, P., S.B. Sjollema, H.G. van der Geest, P.E.G. Leonards, M.H. Lamoree, W.P. de Voogt, W. Admiraal, R.W.P.M. Laane, et al. 2015. Toxic pressure of herbicides on microalgae in Dutch estuarine and coastal waters. Journal of Sea Research 102: 48-56. https://doi.org/10.1016/j.seares.2015.05.001.

Booij, K., C.D. Robinson, R.M. Burgess, P. Mayer, C.A. Roberts, L. Ahrens, I.J. Allan, J. Brant, et al. 2016. Passive sampling in regulatory chemical monitoring of nonpolar organic compounds in the aquatic environment. Environmental Science and Technology 50: 3-17. https://doi.org/10.1021/acs.est.5b04050.

Borecka, M., A. Białk-Bielińska, G. Siedlewicz, K. Kornowska, J. Kumirska, P. Stepnowski, and K. Pazdro. 2013. A new approach for the estimation of expanded uncertainty of results of an analytical method developed for determining antibiotics in seawater using solid-phase extraction disks and liquid chromatography coupled with tandem mass spectrometry technique. Journal of Chromatography A 1304: 138-146. https://doi.org/10. 1016/j.chroma.2013.07.018.

Borecka, M., G. Siedlewicz, ŁP. Haliński, K. Sikora, K. Pazdro, P. Stepnowski, and A. Białk-Bielińska. 2015. Contamination of the southern Baltic Sea waters by the residues of selected pharmaceuticals: Method development and field studies. Marine Pollution Bulletin 94: 62-71. https://doi.org/10.1016/j.marpolbul. 2015.03.008.

Brack, W., S. Ait-Aissa, R.M. Burgess, W. Busch, N. Creusot, C. Di Paolo, B.I. Escher, L. Mark Hewitt, et al. 2016. Effect-directed analysis supporting monitoring of aquatic environments-An indepth overview. Science of the Total Environment 544: 1073-1118. https://doi.org/10.1016/j.scitotenv.2015.11.102. 
Bratkovics, S., and Y. Sapozhnikova. 2011. Determination of seven commonly used organic UV filters in fresh and saline waters by liquid chromatography-tandem mass spectrometry. Analytical Methods 3: 2943-2950. https://doi.org/10.1039/C1AY05390F.

Brausch, J.M., and G.M. Rand. 2011. A review of personal care products in the aquatic environment: Environmental concentrations and toxicity. Chemosphere 82: 1518-1532. https://doi.org/ 10.1016/j.chemosphere.2010.11.018.

Brennan, J.C., R.W. Gale, D.A. Alvarez, J.P. Berninger, J.K. Leet, Y. Li, T. Wagner, and D.E. Tillitt. 2020. Factors affecting sampling strategies for design of an effects-directed analysis for endocrine-active chemicals. Environmental Toxicology and Chemistry 39: 1309-1324. https://doi.org/10.1002/etc.4739.

Brumovský, M., J. Bečanová, P. Karásková, and L. Nizzetto. 2018. Retention performance of three widely used SPE sorbents for the extraction of perfluoroalkyl substances from seawater. Chemosphere 193: 259-269. https://doi.org/10.1016/j.chemosphere. 2017.10.174.

Busetti, F., W.J. Backe, N. Bendixen, U. Maier, B. Place, W. Giger, and J.A. Field. 2012. Trace analysis of environmental matrices by large-volume injection and liquid chromatography-mass spectrometry. Analytical and Bioanalytical Chemistry 402: 175-186. https://doi.org/10.1007/s00216-011-5290-y.

Carere, M., T. Lettieri, A. Wernersson, N. Hanson, S. Buchinger, and R. Kase-Pasanen. Proposal for effect-based monitoring and assessment in the Water Framework Directive. Draft Report to the WG Chemicals on the outcome of the work performed in the subgroup on effect-based methods (EBMs). Draft.

Carlsson, P., and D. Rita. 2019. Sedimentation of Nodularia spumigena and distribution of nodularin in the food web during transport of a cyanobacterial bloom from the Baltic Sea to the Kattegat. Harmful Algae 86: 74-83. https://doi.org/10.1016/j.hal. 2019.05.005

Chapman, P.M. 1990. The sediment quality triad approach to determining pollution-induced degradation. Science of the Total Environment 97-98: 815-825. https://doi.org/10.1016/00489697(90)90277-2.

Concha-Graña, E., G. Fernández-Martínez, P. López-Mahía, D. Prada-Rodríguez, and S. Muniategui-Lorenzo. 2018. Fast and sensitive determination of per- and polyfluoroalkyl substances in seawater. Journal of Chromatography A 1555: 62-73. https:// doi.org/10.1016/j.chroma.2018.04.049.

Cotrim, G., C.S. Fahning, G.O. da Rocha, and V. Hatje. 2016. Endocrine disruptors: Strategies for determination and occurrence in marine environments. Revista de Gestão Costeira Integrada 16: 299-326. https://doi.org/10.5894/rgci669.

Dahlgren, E., D. Lindqvist, H. Dahlgren, L. Asplund, and K. Lehtilä. 2016. Trophic transfer of naturally produced brominated aromatic compounds in a Baltic Sea food chain. Chemosphere 144: 1597-1604. https://doi.org/10.1016/j.chemosphere.2015.10.024.

Davies, I.M., and A.D. Vethaak. 2012. Integrated marine environmental monitoring of chemicals and their effects. ICES Cooperative Research Report No. 315. https://doi.org/10.17895/ices. pub.5403.

De Baat, M.L., M.H.S. Kraak, R. Van der Oost, P. De Voogt, and P.F.M. Verdonschot. 2019. Effect-based nationwide surface water quality assessment to identify ecotoxicological risks. Water Research 159: 434-443. https://doi.org/10.1016/j.watres. 2019.05.040.

Deich, C., M. Kanwischer, M. Jähne, and J.J. Waniek. 2020. Patterns of estrogenic activity in the Baltic Sea. Chemosphere 240: 124870. https://doi.org/10.1016/j.chemosphere.2019.124870.

Dewailly, E., A. Nantel, J.-P. Weber, and F. Meyer. 1989. High levels of PCBs in breast milk of Inuit women from Arctic Quebec. Bulletin of Environmental Contamination and Toxicology 43: 641-646. https://doi.org/10.1007/BF01701981.
DeWitt, J.C. 2015. Toxicological effects of perfluoroalkyl and polyfluoroalkyl substances. In Molecular and integrative toxicology, ed. J.C. DeWitt. Cham: Springer. https://doi.org/10. 1007/978-3-319-15518-0.

Di Paolo, C., R. Ottermanns, S. Keiter, S. Ait-Aissa, K. Bluhm, W. Brack, M. Breitholtz, S. Buchinger, et al. 2016. Bioassay battery interlaboratory investigation of emerging contaminants in spiked water extracts-Towards the implementation of bioanalytical monitoring tools in water quality assessment and monitoring. Water Research 104: 473-484. https://doi.org/10.1016/j.watres. 2016.08.018.

Diamond, J.M., H.A. Latimer, K.R. Munkittrick, K.W. Thornton, S.M. Bartell, and K.A. Kidd. 2011. Prioritizing contaminants of emerging concern for ecological screening assessments. Environmental Toxicology and Chemistry 30: 2385-2394. https://doi. org/10.1002/etc.667.

Díaz-Cruz, M.S., and D. Barceló, ed. 2015. Personal care products in the aquatic environment. In The handbook of environmental chemistry, vol 36. Cham: Springer. https://doi.org/10.1007/9783-319-18809-6.

Duarte, B., C. Gameiro, A.R. Matos, A. Figueiredo, M.S. Silva, C. Cordeiro, I. Caçador, P. Reis-Santos, et al. 2021. First screening of biocides, persistent organic pollutants, pharmaceutical and personal care products in Antarctic phytoplankton from Deception Island by FT-ICR-MS. Chemosphere 274: 129860. https:// doi.org/10.1016/j.chemosphere.2021.129860.

Escher, B.I., C. van Daele, M. Dutt, J.Y.M. Tang, and R. Altenburger. 2013. Most oxidative stress response in water samples comes from unknown chemicals: The need for effect-based water quality trigger values. Environmental Science and Technology 47: 7002-7011. https://doi.org/10.1021/es304793h.

Escher, B.I., M. Allinson, R. Altenburger, P.A. Bain, P. Balaguer, W. Busch, J. Crago, N.D. Denslow, et al. 2014. Benchmarking organic micropollutants in wastewater, recycled water and drinking water with in vitro bioassays. Environmental Science and Technology 48: 1940-1956. https://doi.org/10.1021/es403899t.

Feistel, R., G. Nausch, and N. Wasmund. 2008. State and Evolution of the Baltic Sea, 1952-2005, ed. R. Feistel, G. Nausch, and N. Wasmund. NJ, USA: John Wiley \& Sons, Inc. https://doi.org/10. 1002/9780470283134.

Filipovic, M., U. Berger, and M.S. McLachlan. 2013. Mass balance of perfluoroalkyl acids in the Baltic Sea. Environmental Science and Technology 47: 4088-4095. https://doi.org/10.1021/ es400174y.

Finni, T., K. Kononen, R. Olsonen, and K. Wallström. 2001. The history of cyanobacterial blooms in the Baltic Sea. Ambio: A Journal of the Human Environment 30: 172-178. https://doi.org/ 10.1579/0044-7447-30.4.172.

Fisch, K., J.J. Waniek, and D.E. Schulz-Bull. 2017. Occurrence of pharmaceuticals and UV-filters in riverine run-offs and waters of the German Baltic Sea. Marine Pollution Bulletin 124: 388-399. https://doi.org/10.1016/j.marpolbul.2017.07.057.

Fisch, K., B. Brockmeyer, W. Gerwinski, D.E. Schulz-Bull, and N. Theobald. 2021. Seasonal variability, long-term distribution (2001-2014), and risk assessment of polar organic micropollutants in the Baltic Sea. Environmental Science and Pollution Research. https://doi.org/10.1007/s11356-021-13254-5.

Gao, K., Y. Chen, Q. Xue, Fu. Jie, K. Fu, Fu. Jianjie, A. Zhang, Z. Cai, et al. 2020. Trends and perspectives in per- and polyfluorinated alkyl substances (PFASs) determination: Faster and broader. Trends in Analytical Chemistry 133: 116114. https://doi. org/10.1016/j.trac.2020.116114.

Gaw, S., K.V. Thomas, and T.H. Hutchinson. 2014. Sources, impacts and trends of pharmaceuticals in the marine and coastal environment. Philosophical Transactions of the Royal Society 
B: Biological Sciences 369: 20130572. https://doi.org/10.1098/ rstb.2013.0572.

Gunnarsson, L., A. Jauhiainen, E. Kristiansson, O. Nerman, and D.G.J. Larsson. 2008. Evolutionary conservation of human drug targets in organisms used for environmental risk assessments. Environmental Science and Technology 42: 5807-5813. https:// doi.org/10.1021/es8005173.

Gustavsson. 2010. Comments concerning the National Swedish Contaminant Monitoring Programme in Marine Biota, 2016, 5:2016, vol. 8. , Stockholm: Swedish Museum of Natural History.

Heberer, T., and T. Ternes. 2006. Residues of pharmaceuticals from human use. In Organic pollutants in the water cycle, eds. T. Reemtsma and M. Jekel, 41-63. Weinheim, FRG: WileyVCH Verlag GmbH \& Co. KGaA. https://doi.org/10.1002/ 352760877X.ch2.

HELCOM. 2010. Hazardous Substances in the Baltic Sea-An integrated thematic assessment of hazardous substances in the Baltic Sea. Baltic Sea Environmental Proceedings No. 120 B.

HELCOM. 2018a. Cyanobacterial bloom index. HELCOM pre-core indicator report. Online 15.09.2020 viewed.

HELCOM. 2018b. Inputs of hazardous substances to the Baltic Sea. Baltic Sea Environment Proceedings 162.

HELCOM. 2018c. State of the Baltic Sea-Second HELCOM holistic assessment 2011-2016. Baltic Sea Environment Proceedings 155.

HELCOM. 2018d. Thematic assessment of hazardous substances 2011-2016. Supplementary report to the HELCOM "State of the Baltic Sea" report.

Hettwer, K., M. Jähne, K. Frost, M. Giersberg, G. Kunze, M. Trimborn, M. Reif, J. Türk, et al. 2018. Validation of Arxula Yeast Estrogen Screen assay for detection of estrogenic activity in water samples: Results of an international interlaboratory study. Science of the Total Environment 621: 612-625. https:// doi.org/10.1016/j.scitotenv.2017.11.211.

Heub, S., N. Tscharner, V. Monnier, F. Kehl, P.S. Dittrich, S. Follonier, and L. Barbe. 2015. Automated and portable solid phase extraction platform for immuno-detection of $17 \beta$-estradiol in water. Journal of Chromatography A 1381: 22-28. https://doi. org/10.1016/j.chroma.2014.12.076.

Hogenboom, A.C., J.A. van Leerdam, and P. de Voogt. 2009. Accurate mass screening and identification of emerging contaminants in environmental samples by liquid chromatographyhybrid linear ion trap Orbitrap mass spectrometry. Journal of Chromatography A 1216: 510-519. https://doi.org/10.1016/j. chroma.2008.08.053.

Hollender, J., B. van Bavel, V. Dulio, E. Farmen, K. Furtmann, J. Koschorreck, U. Kunkel, M. Krauss, et al. 2019. High resolution mass spectrometry-based non-target screening can support regulatory environmental monitoring and chemicals management. Environmental Sciences Europe 31: 42. https://doi.org/10. 1186/s12302-019-0225-x.

Hong, S., J.P. Giesy, J.-S. Lee, J.-H. Lee, and J.S. Khim. 2016. Effectdirected analysis: Current status and future challenges. Ocean Science Journal 51: 413-433. https://doi.org/10.1007/s12601016-0038-4.

Horai, H., M. Arita, S. Kanaya, Y. Nihei, T. Ikeda, K. Suwa, Y. Ojima, K. Tanaka, et al. 2010. MassBank: A public repository for sharing mass spectral data for life sciences. Journal of Mass Spectrometry 45: 703-714. https://doi.org/10.1002/jms.1777.

Hotchkiss, A.K., C.V. Rider, C.R. Blystone, V.S. Wilson, P.C. Hartig, G.T. Ankley, P.M. Foster, C.L. Gray, et al. 2008. Fifteen years after "Wingspread"-Environmental endocrine disrupters and human and wildlife health: Where we are today and where we need to go. Toxicological Sciences 105: 235-259. https://doi.org/ 10.1093/toxsci/kfn030.
Jarošová, B., L. Bláha, J.P. Giesy, and K. Hilscherová. 2014. What level of estrogenic activity determined by in vitro assays in municipal waste waters can be considered as safe? Environment International 64: 98-109. https://doi.org/10.1016/j.envint.2013. 12.009 .

Joerss, H., C. Apel, and R. Ebinghaus. 2019. Emerging per- and polyfluoroalkyl substances (PFASs) in surface water and sediment of the North and Baltic Seas. Science of the Total Environment 686: 360-369. https://doi.org/10.1016/j.scitotenv. 2019.05.363.

Johansson, J. 2018. Total and regional runoff to the Baltic Sea. HELCOM Baltic Sea Environment Fact Sheets. http://www. helcom.fi/baltic-sea-trends/environment-fact-sheets/. Accessed 29 May 2020.

Johansson, J., and E. Underman. 2020. Perfluorooctane sulfonate (PFOS) and other perfluorinated alkyl substances (PFASs) in the Baltic Sea-Sources, transport routes and trends. HELCOM Baltic Sea Environmental Proceedings No. 173.

Jones, L., J. Ronan, B. McHugh, and F. Regan. 2019. Passive sampling of polar emerging contaminants in Irish catchments. Water Science and Technology 79: 218-230. https://doi.org/10. 2166/wst.2019.021.

Kanwischer, M., B. Hentzsch, D.E. Schulz-Bull, J. Mannio, H. Nygård, and A. Grimvall. 2019. Towards streamlined Baltic Sea environmental assessment and monitoring-Technical report on improvement of hazardous substances monitoring. BONUS SEAM Project Report.

Kirchgeorg, T., I. Weinberg, A. Dreyer, and R. Ebinghaus. 2010. Perfluorinated compounds in marine surface waters: Data from the Baltic Sea and methodological challenges for future studies. Environmental Chemistry 7: 429. https://doi.org/10.1071/ EN10039.

Kötke, D., J. Gandrass, Z. Xie, and R. Ebinghaus. 2019. Prioritised pharmaceuticals in German estuaries and coastal waters: Occurrence and environmental risk assessment. Environmental Pollution 255: 113161. https://doi.org/10.1016/j.envpol.2019.113161.

Lara-Martín, P.A., A.C. Chiaia-Hernández, M. Biel-Maeso, R.M. Baena-Nogueras, and J. Hollender. 2020. Tracing urban wastewater contaminants into the Atlantic Ocean by nontarget screening. Environmental Science and Technology 54: 3996-4005. https://doi.org/10.1021/acs.est.9b06114.

Leendert, V., H. Van Langenhove, and K. Demeestere. 2015. Trends in liquid chromatography coupled to high-resolution mass spectrometry for multi-residue analysis of organic micropollutants in aquatic environments. Trends in Analytical Chemistry 67: 192-208. https://doi.org/10.1016/j.trac.2015.01.010.

Li, A., F. Ma, X. Song, and R. Yu. 2011. Dynamic adsorption of diarrhetic shellfish poisoning (DSP) toxins in passive sampling relates to pore size distribution of aromatic adsorbent. Journal of Chromatography A 1218: 1437-1442. https://doi.org/10.1016/j. chroma.2011.01.043.

Li, X., J. Chen, X. He, Z. Wang, D. Wu, X. Zheng, L. Zheng, and B. Wang. 2019. Simultaneous determination of neonicotinoids and fipronil and its metabolites in environmental water from coastal bay using disk-based solid-phase extraction and high-performance liquid chromatography-tandem mass spectrometry. Chemosphere 234: 224-231. https://doi.org/10.1016/j.chemosphere. 2019.05.243.

Lian, Z., X. He, and J. Wang. 2014. Determination of sulfadiazine in Jiaozhou Bay using molecularly imprinted solid-phase extraction followed by high-performance liquid chromatography with a diode-array detector. Journal of Chromatography B: Biomedical Sciences and Applications 957: 53-59. https://doi.org/10.1016/j. jchromb.2014.02.053.

Lindqvist, D., and L. Asplund. 2019. Determination of hydroxylated polybrominated diphenyl ethers in blood from Baltic grey seals. 
Journal of Analysis and Testing 3: 287-294. https://doi.org/10. 1007/s41664-019-00084-1.

Lionetto, M.G., R. Caricato, and M.E. Giordano. 2021. Pollution biomarkers in the framework of marine biodiversity conservation: State of art and perspectives. Water. https://doi.org/10. 3390/w13131847.

Löfstrand, K., X. Liu, D. Lindqvist, S. Jensen, and L. Asplund. 2011. Seasonal variations of hydroxylated and methoxylated brominated diphenyl ethers in blue mussels from the Baltic Sea. Chemosphere 84: 527-532. https://doi.org/10.1016/j. chemosphere.2011.01.001.

Lohmann, R., K. Booij, F. Smedes, and B. Vrana. 2012. Use of passive sampling devices for monitoring and compliance checking of POP concentrations in water. Environmental Science and Pollution Research 19: 1885-1895. https://doi.org/10.1007/ s11356-012-0748-9.

Lohrer, C., P.P. Cwierz, M.A. Wirth, D.E. Schulz-Bull, and M. Kanwischer. 2020. Methodological aspects of methylphosphonic acid analysis: Determination in river and coastal water samples. Talanta 211: 120724. https://doi.org/10.1016/j.talanta.2020.120724.

Longnecker, K., and E.B. Kujawinski. 2017. Mining mass spectrometry data: Using new computational tools to find novel organic compounds in complex environmental mixtures. Organic Geochemistry 110: 92-99. https://doi.org/10.1016/j.orggeochem. 2017.05.008.

Loos, R., S. Tavazzi, B. Paracchini, E. Canuti, and C. Weissteiner. 2013. Analysis of polar organic contaminants in surface water of the northern Adriatic Sea by solid-phase extraction followed by ultrahigh-pressure liquid chromatography-QTRAP ${ } M S$ using a hybrid triple-quadrupole linear ion trap instrument. Analytical and Bioanalytical Chemistry 405: 5875-5885. https://doi.org/10. 1007/s00216-013-6944-8.

Magi, E., and M. Di Carro. 2018. Marine environment pollution: The contribution of mass spectrometry to the study of seawater. Mass Spectrometry Reviews 37: 492-512. https://doi.org/10.1002/mas. 21521.

Malmvärn, A., Y. Zebühr, L. Kautsky, Å. Bergman, and L. Asplund. 2008. Hydroxylated and methoxylated polybrominated diphenyl ethers and polybrominated dibenzo-p-dioxins in red alga and cyanobacteria living in the Baltic Sea. Chemosphere 72: 910-916. https://doi.org/10.1016/j.chemosphere.2008.03.036.

Martínez Bueno, M.J., S. Herrera, D. Munaron, C. Boillot, H. Fenet, S. Chiron, and E. Gómez. 2016. POCIS passive samplers as a monitoring tool for pharmaceutical residues and their transformation products in marine environment. Environmental Science and Pollution Research 23: 5019-5029. https://doi.org/10.1007/ s11356-014-3796-5.

Maurer, H.H., and M.R. Meyer. 2016. High-resolution mass spectrometry in toxicology: Current status and future perspectives. Archives of Toxicology 90: 2161-2172. https://doi.org/10.1007/ s00204-016-1764-1.

Mazur, H., and M. Plinski. 2003. Nodularia spumigena blooms and the occurrence of hepatotoxin in the Gulf of Gdańsk. Oceanologica 45: 305-316.

Mengist, W., T. Soromessa, and G. Legese. 2020. Method for conducting systematic literature review and meta-analysis for environmental science research. MethodsX 7: 100777. https:// doi.org/10.1016/j.mex.2019.100777.

Merlo, F., F. Maraschi, D. Piparo, A. Profumo, and A. Speltini. 2020. Simultaneous pre-concentration and HPLC-MS/MS quantification of phycotoxins and cyanotoxins in inland and coastal waters. International Journal of Environmental Research and Public Health. https://doi.org/10.3390/ijerph17134782.

Metzger, M., P. Ley, M. Sturm, and B. Meermann. 2019. Screening method for extractable organically bound fluorine (EOF) in river water samples by means of high-resolution-continuum source graphite furnace molecular absorption spectrometry (HR-CS GF MAS). Analytical and Bioanalytical Chemistry 411: 4647-4660. https://doi.org/10.1007/s00216-019-01698-1.

Moeris, S., F. Vanryckeghem, K. Demeestere, and K.A.C. De Schamphelaere. 2021. A margin of safety approach for the assessment of environmentally realistic chemical mixtures in the marine environment based on combined passive sampling and ecotoxicity testing. Science of the Total Environment 765: 142748. https://doi.org/10.1016/j.scitotenv.2020.142748.

Montesdeoca-Esponda, S., Z. Sosa-Ferrera, and J.J. Santana-Rodríguez. 2012. On-line solid-phase extraction coupled to ultraperformance liquid chromatography with tandem mass spectrometry detection for the determination of benzotriazole UV stabilizers in coastal marine and wastewater samples. Analytical and Bioanalytical Chemistry 403: 867-876. https://doi.org/10. 1007/s00216-012-5906-x.

Morin, N.A.O., N. Mazzella, H.P.H. Arp, J. Randon, J. Camilleri, L. Wiest, M. Coquery, and C. Miège. 2018. Kinetic accumulation processes and models for 43 micropollutants in "pharmaceutical" POCIS. Science of the Total Environment 615: 197-207. https://doi.org/10.1016/j.scitotenv.2017.08.311.

Namieśnik, J., B. Zabiegała, A. Kot-Wasik, M. Partyka, and A. Wasik. 2005. Passive sampling and/or extraction techniques in environmental analysis: A review. Analytical and Bioanalytical Chemistry 381: 279-301. https://doi.org/10.1007/s00216-0042830-8.

Neale, P.A., R. Altenburger, S. Aït-Aïssa, F. Brion, W. Busch, G. de Aragão Umbuzeiro, M.S. Denison, D. Du Pasquier, et al. 2017. Development of a bioanalytical test battery for water quality monitoring: Fingerprinting identified micropollutants and their contribution to effects in surface water. Water Research 123: 734-750. https://doi.org/10.1016/j.watres.2017.07.016.

Nguyen, M.A., K. Wiberg, E. Ribeli, S. Josefsson, M. Futter, J. Gustavsson, and L. Ahrens. 2017. Spatial distribution and source tracing of per- and polyfluoroalkyl substances (PFASs) in surface water in Northern Europe. Environmental Pollution 220: 1438-1446. https://doi.org/10.1016/j.envpol.2016.10.089.

Nödler, K., T. Licha, and D. Voutsa. 2013. Twenty years laterAtrazine concentrations in selected coastal waters of the Mediterranean and the Baltic Sea. Marine Pollution Bulletin 70: 112-118. https://doi.org/10.1016/j.marpolbul.2013.02.018.

Nödler, K., D. Voutsa, and T. Licha. 2014. Polar organic micropollutants in the coastal environment of different marine systems. Marine Pollution Bulletin 85: 50-59. https://doi.org/10.1016/j. marpolbul.2014.06.024.

Noguera-Oviedo, K., and D.S. Aga. 2016. Lessons learned from more than two decades of research on emerging contaminants in the environment. Journal of Hazardous Materials 316: 242-251. https://doi.org/10.1016/j.jhazmat.2016.04.058.

Nordlöf, U., B. Helander, U. Eriksson, Y. Zebühr, and L. Asplund. 2012. Comparison of organohalogen compounds in a whitetailed sea eagle egg laid in 1941 with five eggs from 1996 to 2001. Chemosphere 88: 286-291. https://doi.org/10.1016/j. chemosphere.2012.02.039.

Ojemaye, C.Y., and L. Petrik. 2019. Pharmaceuticals in the marine environment: A review. Environmental Reviews 27: 151-165. https://doi.org/10.1139/er-2018-0054.

Oliveira, H.M., M.A. Segundo, J.L.F.C. Lima, M. Miró, and V. Cerdà. 2010. On-line renewable solid-phase extraction hyphenated to liquid chromatography for the determination of UV filters using bead injection and multisyringe-lab-on-valve approach. Journal of Chromatography A 1217: 3575-3582. https://doi.org/ 10.1016/j.chroma.2010.03.035.

Orlikowska, A., K. Fisch, and D.E. Schulz-Bull. 2015. Organic polar pollutants in surface waters of inland seas. Marine Pollution 
Bulletin 101: 860-866. https://doi.org/10.1016/j.marpolbul.2015. 11.018.

Paíga, P., A. Lolić, F. Hellebuyck, L.H.M.L.M. Santos, M. Correia, and C. Delerue-Matos. 2015. Development of a SPE-UHPLCMS/MS methodology for the determination of non-steroidal antiinflammatory and analgesic pharmaceuticals in seawater. Journal of Pharmaceutical and Biomedical Analysis 106: 61-70. https://doi.org/10.1016/j.jpba.2014.06.017.

Peakall, D.B. 1993. DDE-induced eggshell thinning: An environmental detective story. Environmental Reviews 1: 13-20.

Rainieri, S., A. Barranco, M. Primec, and T. Langerholc. 2017. Occurrence and toxicity of musks and UV filters in the marine environment. Food and Chemical Toxicology 104: 57-68. https://doi.org/10.1016/j.fct.2016.11.012.

Rocha, M.J., M.F.T. Ribeiro, C. Cruzeiro, F. Figueiredo, and E. Rocha. 2012. Development and validation of a GC-MS method for determination of 39 common pesticides in estuarine waterTargeting hazardous amounts in the Douro River Estuary. International Journal of Environmental Analytical Chemistry 92: 1587-1608. https://doi.org/10.1080/03067319.2011.581366.

Rodríguez-González, N., E. Beceiro-González, M.J. González-Castro, and M.F. Alpendurada. 2016. On-line solid-phase extraction method for determination of triazine herbicides and degradation products in seawater by ultra-pressure liquid chromatographytandem mass spectrometry. Journal of Chromatography A 1470: 33-41. https://doi.org/10.1016/j.chroma.2016.10.007.

Rodríguez-González, N., R. Uzal-Varela, M.J. González-Castro, S. Muniategui-Lorenzo, and E. Beceiro-González. 2017. Reliable methods for determination of triazine herbicides and their degradation products in seawater and marine sediments using liquid chromatography-tandem mass spectrometry. Environmental Science and Pollution Research 24: 7764-7775. https://doi. org/10.1007/s11356-017-8389-7.

Ronan, J.M., and B. McHugh. 2013. A sensitive liquid chromatography/tandem mass spectrometry method for the determination of natural and synthetic steroid estrogens in seawater and marine biota, with a focus on proposed Water Framework Directive Environmental Quality Standards. Rapid Communications in Mass Spectrometry 27: 738-746. https://doi.org/10.1002/rcm. 6505.

Routti, H., B. van Bavel, R.J. Letcher, A. Arukwe, S. Chu, and G.W. Gabrielsen. 2009. Concentrations, patterns and metabolites of organochlorine pesticides in relation to xenobiotic phase I and II enzyme activities in ringed seals (Phoca hispida) from Svalbard and the Baltic Sea. Environmental Pollution 157: 2428-2434. https://doi.org/10.1016/j.envpol.2009.03.008.

Ruan, T., and G. Jiang. 2017. Analytical methodology for identification of novel per- and polyfluoroalkyl substances in the environment. Trends in Analytical Chemistry 95: 122-131. https://doi.org/10.1016/j.trac.2017.07.024.

Sánchez-Quiles, D., and A. Tovar-Sánchez. 2015. Are sunscreens a new environmental risk associated with coastal tourism? Environment International 83: 158-170. https://doi.org/10.1016/j. envint.2015.06.007

Schlenk, D., Y. Sapozhnikova, M.A. Irwin, L. Xie, W. Hwang, S. Reddy, B.J. Brownawell, J. Armstrong, et al. 2005. In vivo bioassay-guided fractionation of marine sediment extracts from the southern California Bight, USA, for estrogenic activity. Environmental Toxicology and Chemistry 24: 2820. https://doi. org/10.1897/05-116R.1.

Schmidt, E.M., M.A. Pudenzi, J.M. Santos, C.F.F. Angolini, R.C.L. Pereira, Y.S. Rocha, E. Denisov, E. Damoc, et al. 2018. Petroleomics via Orbitrap mass spectrometry with resolving power above 1000000 at m/z 200. RSC Advances 8: 6183-6191. https://doi.org/10.1039/C7RA12509G.
Schymanski, E.L., J. Jeon, R. Gulde, K. Fenner, M. Ruff, H.P. Singer, and J. Hollender. 2014. Identifying small molecules via high resolution mass spectrometry: Communicating confidence. Environmental Science and Technology 48: 2097-2098. https://doi. org/10.1021/es5002105.

Sipiä, V., H. Kankaanpää, H. Peltonen, M. Vinni, and J. Meriluoto. 2007. Transfer of nodularin to three-spined stickleback (Gasterosteus aculeatus L.), herring (Clupea harengus L.), and salmon (Salmo salar L.) in the northern Baltic Sea. Ecotoxicology and Environmental Safety 66: 421-425. https://doi.org/10. 1016/j.ecoenv.2006.02.006.

Sipiä, V.O., M.-R. Neffling, J.S. Metcalf, S.M.K. Nybom, J.A.O. Meriluoto, and G.A. Codd. 2008. Nodularin in feathers and liver of eiders (Somateria mollissima) caught from the western Gulf of Finland in June-September 2005. Harmful Algae 7: 99-105. https://doi.org/10.1016/j.hal.2007.05.007.

Skeff, W., A. Orlikowska, and D.E. Schulz-Bull. 2017. Methods comparison, transport and distribution of polar herbicides in the Baltic Sea. Marine Pollution Bulletin 114: 1110-1117. https:// doi.org/10.1016/j.marpolbul.2016.10.014.

Smedes, F., and K. Booij. 2012. Guidelines for passive sampling of hydrophobic contaminants in water using silicone rubber samplers. ICES Techniques in Marine Environmental Sciences No. 52. Copenhagen: ICES.

Smedes, F., R.W. Geertsma, T. van der Zande, and K. Booij. 2009. Polymer-water partition coefficients of hydrophobic compounds for passive sampling: Application of cosolvent models for validation. Environmental Science and Technology 43: 7047-7054. https://doi.org/10.1021/es9009376.

Sprengel, J., P.A. Behnisch, H. Besselink, A. Brouwer, and W. Vetter. 2021. In vitro human cell-based TTR-TR $\beta$ CALUX assay indicates thyroid hormone transport disruption of short-chain, medium-chain, and long-chain chlorinated paraffins. Archives of Toxicology. https://doi.org/10.1007/s00204-021-02994-5.

Strynar, M., S. Dagnino, R. McMahen, S. Liang, A. Lindstrom, E. Andersen, L. McMillan, M. Thurman, et al. 2015. Identification of novel perfluoroalkyl ether carboxylic acids (PFECAs) and sulfonic acids (PFESAs) in natural waters using accurate mass time-of-flight mass spectrometry (TOFMS). Environmental Science and Technology 49: 11622-11630. https://doi.org/10. 1021/acs.est.5b01215.

Sulyok, M., D. Stadler, D. Steiner, and R. Krska. 2020. Validation of an LC-MS/MS-based dilute-and-shoot approach for the quantification of $>500$ mycotoxins and other secondary metabolites in food crops: Challenges and solutions. Analytical and Bioanalytical Chemistry 412: 2607-2620. https://doi.org/10.1007/ s00216-020-02489-9.

Taylor, A.C., G.R. Fones, B. Vrana, and G.A. Mills. 2019. Applications for passive sampling of hydrophobic organic contaminants in water-A review. Critical Reviews in Analytical Chemistry. https://doi.org/10.1080/10408347.2019.1675043.

Theobald, N., C. Caliebe, W. Gerwinski, H. Hühnerfuss, and P. Lepom. 2011. Occurrence of perfluorinated organic acids in the North and Baltic Seas. Part 1: Distribution in sea water. Environmental Science and Pollution Research 18: 1057-1069. https://doi.org/10.1007/s11356-011-0451-2.

Tufi, S., P.N.H. Wassenaar, V. Osorio, J. de Boer, P.E.G. Leonards, and M.H. Lamoree. 2016. Pesticide mixture toxicity in surface water extracts in snails (Lymnaea stagnalis) by an in vitro acetylcholinesterase inhibition assay and metabolomics. Environmental Science and Technology 50: 3937-3944. https://doi. org/10.1021/acs.est.5b04577.

UNESCO and HELCOM. 2017. Pharmaceuticals in the aquatic environment of the Baltic Sea region-A status report. UNESCO Emerging Pollutants in Water Series-No. 1. Paris: UNESCO Publishing. 
Vanryckeghem, F., S. Huysman, H. Van Langenhove, L. Vanhaecke, and K. Demeestere. 2019. Multi-residue quantification and screening of emerging organic micropollutants in the Belgian Part of the North Sea by use of Speedisk extraction and Q-Orbitrap HRMS. Marine Pollution Bulletin 142: 350-360. https://doi.org/10.1016/j.marpolbul.2019.03.049.

Vrana, B., I.J. Allan, R. Greenwood, G.A. Mills, E. Dominiak, K. Svensson, J. Knutsson, and G. Morrison. 2005. Passive sampling techniques for monitoring pollutants in water. Trends in Analytical Chemistry 24: 845-868. https://doi.org/10.1016/j. trac.2005.06.006.

Wang, M., J.J. Carver, V.V. Phelan, L.M. Sanchez, N. Garg, Y. Peng, D.D. Nguyen, J. Watrous, et al. 2016. Sharing and community curation of mass spectrometry data with Global Natural Products Social Molecular Networking. Nature Biotechnology 34: 828-837. https://doi.org/10.1038/nbt.3597.

Wang, Z., J.C. DeWitt, C.P. Higgins, and I.T. Cousins. 2017. A never-ending story of per- and polyfluoroalkyl substances (PFASs)? Environmental Science and Technology 51: 2508-2518. https://doi.org/10.1021/acs.est.6b04806.

Wang, J., J. Chen, X. He, S. Hao, Y. Wang, X. Zheng, and B. Wang. 2021. Simple determination of six groups of lipophilic marine algal toxins in seawater by automated on-line solid phase extraction coupled to liquid chromatography-tandem mass spectrometry. Chemosphere 262: 128374. https://doi.org/10. 1016/j.chemosphere.2020.128374.

Wernersson, A., C. Maggi, and M. Carere. 2014. Technical report on aquatic effect-based monitoring tools. Technical Report 2014-077. Luxembourg: Office for Official Publications of the European Communities. https://doi.org/10.2779/7260.

Wernersson, A.-S., M. Carere, C. Maggi, P. Tusil, P. Soldan, A. James, W. Sanchez, V. Dulio, et al. 2015. The European Technical Report on aquatic effect-based monitoring tools under the Water Framework Directive. Environmental Sciences Europe 27: 7. https://doi.org/10.1186/s12302-015-0039-4.

Wille, K., H.F. De Brabander, L. Vanhaecke, E. De Wulf, P. Van Caeter, and C.R. Janssen. 2012. Coupled chromatographic and mass-spectrometric techniques for the analysis of emerging pollutants in the aquatic environment. Trends in Analytical Chemistry 35: 87-108. https://doi.org/10.1016/j.trac.2011.12. 003.

Wirth, M.A., M. Sievers, F. Habedank, U. Kragl, D.E. Schulz-Bull, and M. Kanwischer. 2019. Electrodialysis as a sample processing tool for bulk organic matter and target pollutant analysis of seawater. Marine Chemistry 217: 103719. https://doi.org/10. 1016/j.marchem.2019.103719.

Wirth, M.A., D.E. Schulz-Bull, and M. Kanwischer. 2021. The challenge of detecting the herbicide glyphosate and its metabolite AMPA in seawater-Method development and application in the Baltic Sea. Chemosphere 262: 128327. https://doi.org/10. 1016/j.chemosphere.2020.128327.

Xiao, K., N. Zhu, Z. Lu, H. Zheng, C. Cui, Y. Gao, Y. Gao, X. Meng, et al. 2021. Distribution of eight organophosphorus pesticides and their oxides in surface water of the East China Sea based on high volume solid phase extraction method. Environmental Pollution 279: 116886. https://doi.org/10.1016/j.envpol.2021. 116886.

Zendong, Z., M. Kadiri, C. Herrenknecht, E. Nézan, A. Mazzeo, and P. Hess. 2016. Algal toxin profiles in Nigerian coastal waters (Gulf of Guinea) using passive sampling and liquid chromatography coupled to mass spectrometry. Toxicon 114: 16-27. https://doi.org/10.1016/j.toxicon.2016.02.011.

Zhang, Y., D. Chen, Z. Hong, S. Zhou, and Y. Zhao. 2018. Polymeric ion exchange material based dispersive micro solid-phase extraction of lipophilic marine toxins in seawater followed by the Q Exactive mass spectrometer analysis using a scheduled high resolution parallel reaction monitoring. Microchemical Journal 138: 526-532. https://doi.org/10.1016/j.microc.2018.02. 005.

Zubarev, R.A., and A. Makarov. 2013. Orbitrap mass spectrometry. Analytical Chemistry 85: 5288-5296. https://doi.org/10.1021/ ac4001223.

Zwart, N., S.L. Nio, C.J. Houtman, J. de Boer, J. Kool, T. Hamers, and M.H. Lamoree. 2018. High-throughput effect-directed analysis using downscaled in vitro reporter gene assays to identify endocrine disruptors in surface water. Environmental Science and Technology 52: 4367-4377. https://doi.org/10.1021/ acs.est.7b06604.

Publisher's Note Springer Nature remains neutral with regard to jurisdictional claims in published maps and institutional affiliations.

\section{AUTHOR BIOGRAPHIES}

Marion Kanwischer $(\square)$ is a Senior Scientist at the Leibniz Institute for Baltic Sea Research Warnemünde. Her research interests include the analysis of occurrence, fate and transport of natural and anthropogenic organic trace substances in the marine environment.

Address: Department of Marine Chemistry, Leibniz Institute for Baltic Sea Research Warnemünde, Seestraße 15, 18119 Rostock, Germany.

e-mail: marion.kanwischer@io-warnemuende.de

Noomi Asker is Researcher at the University of Gothenburg. Her research interests include aquatic ecotoxicology and the use of effect based methods.

Address: Department of Biological and Environmental Sciences, University of Gothenburg, Medicinaregatan 18A, 41390 Göteborg, Sweden.

e-mail: noomi.asker@bioenv.gu.se

Ann-Sofie Wernersson is a Researcher at the Swedish Geotechnical Institute. Her research interests include aquatic ecotoxicology and implementation of environmental policy and water legislation.

Address: Department for Management of Contaminated Sites, Swedish Geotechnical Institute, Hugo Grauers gata 5 B, 41296 Göteborg, Sweden.

e-mail: Ann-Sofie.Wernersson@sgi.se

Marisa A. Wirth is a Researcher at the Leibniz Institute for Baltic Sea Research Warnemünde. Her research interests include the analysis of occurrence, fate and transport of polar organic compounds in the environment, as well as the development of suitable analysis methods for their assessment.

Address: Department of Marine Chemistry, Leibniz Institute for Baltic Sea Research Warnemünde, Seestraße 15, 18119 Rostock, Germany.

e-mail: marisa.wirth@io-warnemuende.de

Kathrin Fisch is a Researcher at the Leibniz Institute for Baltic Sea Research Warnemünde. Her research interests include the contaminants of emerging concern such as pharmaceuticals and personal care products in the marine environment.

Address: Department of Marine Chemistry, Leibniz Institute for Baltic Sea Research Warnemünde, Seestraße 15, 18119 Rostock, Germany.

e-mail: kathrin.fisch@io-warnemuende.de

Elin Dahlgren is a Researcher at the Swedish University of Agricultural Sciences. Her research examines the production, flow and effects of algal toxins and vitamins in aquatic ecosystems. 
Address: Swedish University of Agricultural Sciences, Stångholmsvägen 2, 17893 Drottningholm, Sweden.

e-mail: Elin.Dahlgren@slu.se

Helena Osterholz is a Researcher at the Leibniz Institute for Baltic Sea Research Warnemünde. Her research focuses on composition and turnover of natural and anthropogenic organic compounds in aquatic environments.

Address: Department of Marine Chemistry, Leibniz Institute for Baltic Sea Research Warnemünde, Seestraße 15, 18119 Rostock, Germany.

e-mail: helena.osterholz@io-warnemuende.de

Friederike Habedank is the Head of the Lab for Residue Analysis of Pesticides and Organic Contaminants at the State Office for Agriculture, Food Safety and Fisheries Mecklenburg-Western Pomerania. Her research interests include food analysis and hyphenated mass spectrometry.

Address: State Office for Agriculture, Food Safety and Fisheries, Mecklenburg-Western Pomerania, Thierfelderstraße 18, 18059 Rostock, Germany.

e-mail: friederike.habedank@lallf.mvnet.de

Michael Naumann is a Senior Scientist at the Leibniz Institute for Baltic Sea Research Warnemünde. His current research interests include hydrographical-hydrochemical changes on long time scales, water exchange processes and oxygen depletion/hypoxic conditions in the Baltic Sea ecosystem.

Address: Department of Physical Oceanography and Instrumentation, Leibniz Institute for Baltic Sea Research Warnemünde, Seestraße 15, 18119 Rostock, Germany.

e-mail: michael.naumann@io-warnemuende.de

Jaakko Mannio is Leading Scientist at the Finnish Environment Institute and his current activity is on screening new chemicals in aquatic environments and design and harmonization of national, regional and European monitoring activities for contaminants.

Address: Centre for Sustainable Consumption and Production/Contaminants, Finnish Environment Institute, Latokartanonkaari 11, 00790 Helsinki, Finland.

e-mail: jaakko.mannio@syke.fi

Detlef E. Schulz-Bull is Professor at the University of Rostock and Head of Department of Marine Chemistry as well as Deputy Director of the Leibniz Institute for Baltic Sea Research Warnemünde. His research interests include anthropogenic organic trace substances and natural organic material in the marine environment.

Address: Department of Marine Chemistry, Leibniz Institute for Baltic Sea Research Warnemünde, Seestraße 15, 18119 Rostock, Germany.

e-mail: detlef.schulz-bull@io-warnemuende.de 